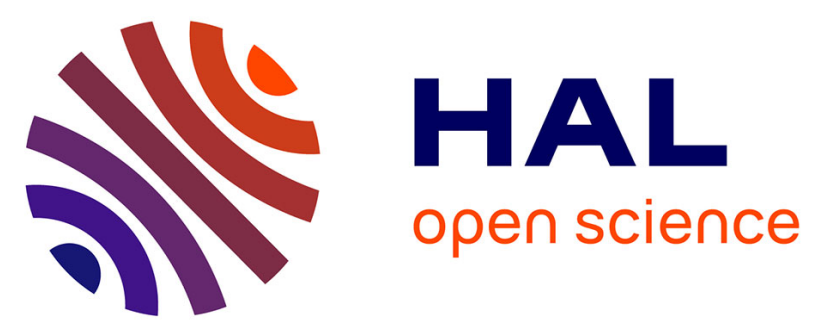

\title{
Brainstem metabotropic glutamate receptors reduce food intake and activate dorsal pontine and medullar structures after peripheral bacterial lipopolysaccharide administration
}

Léa Chaskiel, Flora Paul, Rüdiger Gerstberger, Thomas Hübschle, Jan Pieter

Konsman

\section{To cite this version:}

Léa Chaskiel, Flora Paul, Rüdiger Gerstberger, Thomas Hübschle, Jan Pieter Konsman. Brainstem metabotropic glutamate receptors reduce food intake and activate dorsal pontine and medullar structures after peripheral bacterial lipopolysaccharide administration. Neuropharmacology, 2016, 107, pp.146 - 159. 10.1016/j.neuropharm.2016.03.030 . hal-03177023

\author{
HAL Id: hal-03177023 \\ https://hal.science/hal-03177023
}

Submitted on 22 Mar 2021

HAL is a multi-disciplinary open access archive for the deposit and dissemination of scientific research documents, whether they are published or not. The documents may come from teaching and research institutions in France or abroad, or from public or private research centers.
L'archive ouverte pluridisciplinaire HAL, est destinée au dépôt et à la diffusion de documents scientifiques de niveau recherche, publiés ou non, émanant des établissements d'enseignement et de recherche français ou étrangers, des laboratoires publics ou privés. 
Published in Neuropharmacology, 2016 Aug;107:146-159. doi: 10.1016/j.neuropharm.2016.03.030

\section{Brainstem metabotropic glutamate receptors reduce food intake and activate dorsal} pontine and medullar structures after peripheral bacterial lipopolysaccharide administration

Léa Chaskiel $^{\mathrm{a}, \mathrm{b}}$, Flora Paul ${ }^{\mathrm{a}, \mathrm{b}}$, Rüdiger Gerstberger ${ }^{\mathrm{c}}$, Thomas Hübschle ${ }^{\mathrm{c}}$ and Jan Pieter

$$
\operatorname{Konsman}^{\mathrm{a}, \mathrm{b}_{*}}
$$

${ }^{a}$ CNRS, PsychoNeuroImmunologie, Nutrition et Génétique, UMR 5226, Bordeaux, France

${ }^{\mathrm{b}}$ Univ. Bordeaux, PsyNuGen, UMR 5226, Bordeaux, France

${ }^{\mathrm{c}}$ Institut für Veterinär-Physiologie und -Biochemie, Justus-Liebig-Universität Giessen, 35392

Giessen, Germany

Abbreviated title: Brainstem metabotropic glutamate receptors reduce food intake

* Corresponding author. Present address:

Jan Pieter Konsman, CNRS UMR 5536, Résonance Magnétique des Systèmes Biologiques, Université de Bordeaux, 146, rue Léo Saignat, 33076 Bordeaux Cedex, France

Phone: +33 557571074

Fax: +33 557574556

E-mail: jan-pieter.konsman@u-bordeaux2.fr 
During infection-induced inflammation food intake is reduced. Vagal and brainstem pathways are important both in feeding regulation and immune-to-brain communication. Glutamate is released by vagal afferent terminals in the nucleus of the solitary tract and by its neurons projecting to the parabrachial nuclei. We therefore studied the role of brainstem glutamate receptors in spontaneous food intake of healthy animals and during sicknessassociated hypophagia after peripheral administration of bacterial lipopolysaccharides or interleukin-1beta. Brainstem group I and II metabotropic, but not ionotropic, glutamate receptor antagonism increased food intake both in saline- and lipopolysaccharide-treated rats. In these animals, expression of the cellular activation marker c-Fos in the lateral parabrachial nuclei and lipopolysaccharide-induced activation of the nucleus of the solitary tract rostral to the area postrema were suppressed. Group I metabotropic glutamate receptors did not colocalize with c-Fos or neurons regulating gastric function in these structures. Group I metabotropic glutamate receptors were, however, found on raphé magnus neurons that were part of the brainstem circuit innervating the stomach and on trigeminal and hypoglossal motor neurons. In conclusion, our findings show that brainstem metabotropic glutamate receptors reduce food intake and activate the lateral parabrachial nuclei as well as the rostral nucleus of the solitary tract after peripheral bacterial lipopolysaccharide administration. They also provide insight into potential group I metabotropic glutamate receptor-dependent brainstem circuits mediating these effects. 


\section{Introduction}

The regulation of food intake by the nervous system is thought to involve energy homeostasis and emergency feeding systems (Morton et al. 2014). The latter may temporarily override the former either by stimulating feeding when hypoglycemia occurs or by inhibiting food intake when the organism is faced with infection, trauma or threats from its environment (Morton et al. 2014). Temporary hypophagia may constitute an evolutionary-conserved adaptive response to acute infection (Konsman and Dantzer 2001), even though long-term lowered food consumption is potentially deleterious in chronic inflammatory diseases.

Recently, a brainstem projection from the nucleus of the solitary tract (NTS) to the lateral parabrachial (PB) nuclei has been shown to reduce food intake (Wu et al. 2012). The NTS, in turn, is innervated by neuropeptidergic fibers from the hypothalamus, serotonergic neurons in the raphé magnus (RM) and glutamate-containing afferents of the gustatory and vagus nerves (Grill 2010; Wu et al. 2012). Administration of $\alpha$-amino-3-hydroxy-5-methyl-4isoxazolepropionic acid (AMPA) and N-methyl-D-aspartic acid (NMDA) glutamate receptor antagonists in the dorsocaudal brainstem attenuates neuronal activation in the NTS after gustatory or gastric stimulation (Li and Smith 1997; Zhang and Fogel 2003) and modulates ingestion of palatable food and deprivation-induced intake (Treece et al. 1998; Zheng et al. 2002; Guard et al. 2009). These observations indicate that glutamate action in the NTS is involved in the regulation of feeding when the motivation to eat is high.

The projections of the NTS, in particular from its rostral part, to the PB nuclei also contain glutamate (Gill et al. 1999). These projections seem to be activated by visceral malaise as intraperitoneal injection of $\mathrm{LiCl}$ increases extracellular glutamate in the PB nuclei (Bielavska et al. 2000). Interestingly, inhibition of calcitonin gene-related peptide (CGRP)-expressing neurons of the lateral PB nucleus attenuates the reduction in food intake after the peripheral administration of $\mathrm{LiCl}$ or bacterial lipopolysaccharides (LPS) (Carter et al. 2013). However, 
the neuronal mechanisms and brainstem circuits underlying LPS-induced hypophagia remain to be fully elucidated.

The vagus nerve expresses the LPS-recognizing Toll-like receptor-4 (TLR4) (Hosoi et al. 2005) and the signaling receptor IL-1R1 for the pro-inflammatory cytokine interleukin-1beta (IL-1beta) (Ek et al. 1998). Alternatively, circulating LPS and IL-1beta can act in the area postrema (AP) that lacks a functional endothelial blood-brain barrier (Van Houten and Posner 1983) but contains TLR4- and IL-1R1-expressing cells (Ericsson et al. 1995; Laflamme and Rivest 2001). Regardless of their exact sites of action, peripheral LPS or IL-1beta administration results in glutamate release in the NTS (Mascarucci et al. 1998). Interestingly, peripheral administration of a group I and II metabotropic glutamate receptor (mGluR) antagonist attenuates the reduction in food intake and body weight observed after bacterial LPS injection (Weiland et al. 2006), but the extent to which this antagonist penetrates the brain is unknown.

In the present work, we studied the role of brainstem glutamate receptors in the regulation of spontaneous intake of regular chow in healthy animals and in sickness-associated hypophagia brought about by peripheral LPS or IL-1beta administration. For those glutamate receptor antagonists that had an effect on food intake, we analyzed the brainstem distribution of the targeted receptors and assessed c-Fos expression in the NTS, PB nuclei and RM. Gastric motility is important in the regulation of food intake and controlled by neurons of the dorsal motor nucleus of the vagus nerve (DMV), which, in turn, are contacted by neurons of the NTS, PB nuclei and different raphé nuclei (Rinaman et al. 1993).We therefore also studied the presence of glutamate receptors in the brainstem neuronal network controlling gastric motility. 


\section{Materials and Methods}

\subsection{Animals}

Experiments, including surgical procedures and treatments, were conducted according to local and European recommendations on animal research (ethics approval number GI 18/2 No. 13/2002 and European Council Directive of 24 November 1986 (86/609/EEC)).

2.1.1 Pharmacological studies. One hundred and eighty-seven male Wistar Han rats (Charles River, L'Arbresle, France), weighing between 250 and 275 g upon arrivals were used. After one week of acclimation in group cages, rats were housed individually two days prior to surgery with ad libitum access to food and water in a temperature $\left(22 \pm 1{ }^{\circ} \mathrm{C}\right)$ controlled environment where lights were on from 07:00 to 19:00 h.

2.1.2 Neuroanatomical tracing studies. Ten male Wistar rats with a mean body weight of $230 \mathrm{~g}$ were housed individually with free access to water and standard laboratory chow. Room temperature was adjusted to $23 \pm 1{ }^{\circ} \mathrm{C}$ at relative humidity of $50-55 \%$, and lights were on from 07:00 to 19:00 h.

\subsection{Surgery}

2.2.1 Guide cannula placement. Rats were anesthetized with $61 \mathrm{mg} / \mathrm{kg}$ ketamine (Imalgene 1000, Rhône Mérieux, Lyon, France) and 9 mg/kg xylazine (Bayer Pharma, Puteaux, France) administered intraperitoneally, and secured in a stereotactic apparatus (David Kopf Instruments, Tujunga, CA, USA). A midline incision was made into the skin covering the skull and skin flaps were pulled aside. A stainless-steel $12 \mathrm{~mm}$ long guide cannula (23 gauge) was lowered on the midline, $4.5 \mathrm{~mm}$ below the cortical surface through a hole drilled in the skull $2.5 \mathrm{~mm}$ posterior to lambda corresponding to bregma -11.5 and permanently fixed to the skull with dental cement and watchmakers' screws. These coordinates were chosen to position the tip of this guide cannula $2 \mathrm{~mm}$ above the roof of the $4^{\text {th }}$ ventricle at a level where this 
ventricle it relatively large and profound. The head wound was closed by suturing skin flaps and rats were allowed to recover for at least one week during which they were handled daily before injections.

2.2.2 Neurotropic virus injection. Attenuated Bartha pseudorabies virus (PRV-Ba) was used to trace the efferent neural pathways regulating gastric motility and secretion. PRV-Ba propagated as previously described (Yoshida et al. 2003) and stocked at a concentration of $8.03 \mathrm{TCID} 50 / \mathrm{mL}$ at $-70^{\circ} \mathrm{C}$ until use. Rats were anesthetized with intraperitoneal injections of ketamine-xylazine solution (100 mg/kg ketamine hydrochloride (Pharmacia Upjohn, Erlangen, Germany) and $25 \mathrm{mg} / \mathrm{kg}$ Rompun (Bayer Vital, Leverkusen, Germany). A midline laparotomy was made to expose the stomach and approximately $0.7 \mu 1$ of $10^{8} \mathrm{pfu} / \mathrm{ml} \mathrm{PRV-Ba}$ was injected at five sites in the stomach wall along its great curvature with a 5- $\mu$ l syringe (Hamilton, Bonaduz, Switzerland) that was kept in place for $30 \mathrm{~s}$ after injection. Any efflux from the injection site was immediately adsorbed with sterile cotton buds after which the wound was closed. After wake up and recovery for several day, rats were deeply anesthetized and killed for transcardial perfusion-fixation after $54 \mathrm{~h}(\mathrm{n}=1)$, when cell bodies of neurons in the DMV that project to the stomach via the vagus nerve can be expected to be infected, $72 \mathrm{~h}$ $(n=3)$, corresponding to the published infection of the first second orders in the NTS and the area postrema, or 96-102 $\mathrm{h}(\mathrm{n}=6)$ during which the density of infected medullary neurons is reported to reach its maximum (Rinaman et al. 1993).

\subsection{Treatments}

For the studies addressing the effects of AMPA/kainate and metabotropic glutamate receptor antagonism, two sets of experiments we performed. In the series of experiments designated for c-Fos immunohistochemistry, the effects of intra-4th ventricle (i4v) glutamate receptor antagonism on inflammatory hypophagia and weight loss were assessed until $6 \mathrm{~h}$ after intraperitoneal (ip) injection of LPS or its saline vehicle. In another set of experiments, 
the effects of $\mathrm{i} 4 \mathrm{v}$ glutamate receptor antagonism on inflammatory hypophagia and weight loss were compared between ip IL-1beta and LPS. These latter series were set up so that at the end of the experiment all animals had received a glutamate receptor antagonist and its vehicle centrally and a pro-inflammatory stimulus, consisting of either IL-1beta or LPS and their vehicles peripherally. Thus, if one week after i4v administration and subsequent ip injection, food and water intake as well as body weight had returned to levels observed before treatment for at least three days, the experiment was repeated inversing i4v and ip treatments. The order of administration of the inflammatory stimulus (IL-1beta or LPS) between the two injections was determined by coin toss.

Given 1) that the NMDA glutamate receptor requires membrane depolarization to remove the $\mathrm{Mg}^{2+}$ ion blocking this channel before it can become active (Nowak et al. 1984) and 2) that $97 \%$ of NTS neurons containing the calcium-permeable AMPA-receptor subunit also express the NMDA receptor and vice versa (Lin and Talman 2002), we decided to only perform an experiment with an NMDA receptor antagonist in case of a positive effect of AMPA/kainate/quisqualate receptor antagonism on food intake was observed.

2.3.1 Intra- $4^{\text {th }}$ ventricle (i4v) administration of glutamate receptor antagonists. A 30 gauge (14 mm long) injection cannula filled with glutamate receptor antagonists or their vehicle and connected to a $10 \mu \mathrm{l}$ syringe (Hamilton, Villebon sur Yvette, France) with plastic tubing was lowered through the guide cannula into the $4^{\text {th }}$ ventricle.

The AMPA/kainate/quisqualate water soluble receptor antagonist 6-cyano-7nitroquinoxaline-2-3-dione (CNQX; Alexis Biochemicals, Enzo Life Sciences, Vileurbanne, France) was dissolved in $2 \mu \mathrm{l}$ phosphate-buffered saline (PBS $0.1 \mathrm{M} ; \mathrm{pH}$ 7.4) and administered at a dose of $23.2 \mathrm{nmol}(6.4 \mu \mathrm{g})$ per animal into the 4th ventricle based on the following findings: 1) $1.2 \mathrm{nmol}$ CNQX injected directly into the dorsal vagal complex containing the NTS and DMV attenuates gastrointestinal vago-vagal reflexes initiated by 
gastrointestinal distention in the rat (Zhang and Fogel 2003) and 2) i4v administration of 5 nmol $(0.46 \mu \mathrm{g})$ of the AMPA/kainate receptor antagonist 6-nitro-7sulphamoylbenzo[f]quinoxaline-2,3-dione (NBQX) attenuates sucrose intake (Zheng et al. 2002) and 3) taking into consideration that CNQX is about 4.5 times less potent than NBQX in displacing binding to AMPA receptors (Dev et al. 1996).

Since one of our aims was to determine if the effects of the peripheral administration of the metabotropic glutamate receptor antagonists on LPS-induced hypophagia observed by Weiland and colleagues (2006) were due to a brainstem site of action, we used the same group I and II mGluR antagonist L(+)-2-amino-3-3-phosphonoproprionic acid (AP3; Sigma, StFallavier, France). In the present work, it was dissolved in PBS (0.1 M; pH 7.4) and used at a dose of $237 \mathrm{nmol}(40 \mu \mathrm{g})$ per animal given into the $4^{\text {th }}$ ventricle based on the finding that administration of $60 \mathrm{nmol}$ AP3 in the smaller intrathecal spinal CSF compartment reduces inflammatory hyperalgesia (Young et al. 1997).

Since the PB and medial NTS are located adjacent to the $4^{\text {th }}$ ventricle, glutamate receptors in these structures were targeted by $\mathrm{i} 4 \mathrm{v}$ administration of antagonists. This route allows for administration of relatively concentrated solutions compared to intraparenchymal injection while keeping the risks of side effects low. Indeed, i4v administered molecules are diluted in the $10 \mu$ l cerebrospinal fluid (CSF) of the $4^{\text {th }}$ ventricle (Levinger 1971) with which it rapidly leaves the ventricular space to the subarachnoid space via CSF convection and bulk (Pardridge 2011). Instead, the entry of molecules from the CSF into the brain parenchyma occurs through diffusion, which is a much slower process than CSF convection and bulk flow. Moreover, the concentration of a diffusing molecule decreases exponentially with diffusion distance. Thus, the concentration of a small molecule in the brain parenchyma $1 \mathrm{~mm}$ beyond the ependymal surface of the ventricles is only $1 \%$ of its CSF concentration (Pardridge 2011). Keeping this in mind, it is important to point out that the dose of CNQX injected into the $4^{\text {th }}$ 
ventricle ( $5 \mathrm{nmol}$ or $0.46 \mu \mathrm{g}$ ) was already lower than that given locally into the PB shown to decrease tachycardia and pressor responses after stimulation of the hypothalamic defense area (Diaz-Casares et al. 2012). Considering its dilution in the CSF and the rapid decrease of its concentration during diffusion into the parenchyma, CNQX was therefore not expected to yield any cardiovascular side effects in the present work.

As for the dose of $\mathrm{i} 4 \mathrm{v}$ AP3 $(0.237 \mu \mathrm{mol}$ or $40 \mu \mathrm{g})$ administered into the fourth ventricle it is not expected to have any non-specific effects on behavior since injection of up to $200 \mu \mathrm{g}$ into the lateral cerebral ventricle (40 $\mu$ l volume (Levinger 1971)) does not affect spontaneous locomotor activity (Winnicka et al. 1994). The dose of AP3 used in the present work is estimated to have resulted in a concentration gradient of $2.4 \mathrm{mM}$ to $0.024 \mathrm{mM}$ in the NTS between the surface and $1 \mathrm{~mm}$ below the surface of the fourth ventricle, respectively. These concentrations are still lower than the $30 \mathrm{mM}$ of AP3 that has been shown to result in a transient decrease of $10 \mathrm{~mm} \mathrm{Hg}$ in blood pressure from a baseline of $100 \mathrm{~mm} \mathrm{Hg}$ when injected into the NTS or ventrolateral medulla in rats (Vitagliano et al., Neuropharmacology, 1994). Similarly, the dose of i4v AP3 administered is expected to have resulted in concentration gradient of $2.4 \mathrm{mM}$ to $0.024 \mathrm{mM}$ in the $\mathrm{PB}$ between the part facing the ventricular surface and $1 \mathrm{~mm}$ beyond it. This concentration gradient in the PB covers that known to block the acquisition of conditioned taste aversion (0.1-5 nM (Vales et al. 2006)). Thus, the dose of AP3 administered into the fourth ventricle is expected to have minimal behavioral and cardiovascular side effects while likely antagonizing brainstem mechanisms that occur after systemic LPS injection, such as the learning of the association of a particular taste with visceral malaise (Cross-Mellor et al. 2004).

The $2 \mu 1$ containing glutamate receptor antagonists or their vehicle were injected over two minutes after which the injection cannula was left in place in the $4^{\text {th }}$ ventricle for an additional minute. Intra-4th ventricle injection was completed 45 minutes before IL-1 or PBS 
administration and just before LPS or saline injection, since IL-1beta can be detected in macrophages and dendritic cells in proximity of the vagus nerve 45 minutes after intraperitoneal LPS injection (Goehler et al. 1999).

2.3.2 Intraperitoneal (ip) injections. E. coli LPS (200 $\mu \mathrm{g} / \mathrm{kg} ; 0127: \mathrm{B} 8$, Sigma, St Louis, MO, USA) or its vehicle $0.9 \% \mathrm{NaCl}$ was injected intraperitoneally $2 \mathrm{~h}$ before lights went off. Rat recombinant IL-1 $\beta(30 \mu \mathrm{g} / \mathrm{kg}$, (Anforth et al. 1998)) or its vehicle PBS was injected into the peritoneal cavity $1 \mathrm{~h}$ before lights went off. This difference in timing of the administration of these two inflammatory stimuli was motivated by the finding that IL-1beta can be detected in macrophages and dendritic cells in proximity of the vagus nerve 45 minutes and in plasma 60 minutes after intraperitoneal LPS injection (Goehler et al. 1999).

2.4 Food intake and body weight measurements. Since food restriction prior to administration of bacterial LPS has been shown to affect subsequent hypophagia and weight loss (MacDonald et al. 2014), the effects of inflammatory stimuli on these parameters were studied in spontaneously-feeding animals with ad libitum access to regular chow for the entire light-dark cycle. As rats show a peak of spontaneous feeding during the first hours of the dark, injections were timed to produce their maximum effect during this period. Food intake and body weight changes were obtained by measuring food ruffs and rats just before and every $2 \mathrm{~h}$ until $6 \mathrm{~h}$ after ip injection on a high-precision balance equipped with an integrator to correct for movement. Animals were habituated to this procedure for at least three days prior to the day of experiment.

In spite of the fact that all rats show a peak of food intake during the first hours of the dark phase when provided ad libitum access to food, each individual still has its own meal pattern, which is mostly repeated from day to day (van Dijk and Strubbe 2003). Cumulative food intake and changes in body weight over periods longer than $2 \mathrm{~h}$ (that is $0-4 \mathrm{~h} ; 0-6 \mathrm{~h}$ and $2-6 \mathrm{~h}$ ) 
were therefore favored for data presentation and analysis, even though food intake and changes in body weight were also analyzed over consecutive $2 \mathrm{~h}$ time windows.

\subsection{Immunohistochemistry}

Six hours after ip injection of saline or LPS, when animals are expected to have consumed food during the first four hours of their active phase and c-Fos expression in the caudal brainstem in response to comparable doses of LPS to still be high (Konsman et al. 1999), animals were deeply anesthetized with pentobarbital $(60 \mathrm{mg} / \mathrm{kg})$. Once the hind paw reflex upon plantar pinching had disappeared, animals were fixed by intracardiac perfusion of $4 \%$ paraformaldehyde in $0.1 \mathrm{M}$ PBS $\left(\mathrm{pH} 7.5\right.$ at $10{ }^{\circ} \mathrm{C}$ for $15 \mathrm{~min}$ ) after a short rinse with $0.1 \mathrm{M}$ PBS. The brain was removed from the skull, post-fixed for $4 \mathrm{~h}$ in the same fixative and cryoprotected in $30 \%$ sucrose in $0.1 \mathrm{M}$ PBS for $48 \mathrm{~h}$. Brains were deep frozen and stored at $80{ }^{\circ} \mathrm{C}$ until they were cut in $25 \mu \mathrm{m}$-thick sections on a cryostat. Brain sections were collected in cold cryoprotectant ( $0.05 \mathrm{M}$ phosphate buffer, $20 \%$ glycerol and 30\% ethylene glycol) and stored at $-20^{\circ} \mathrm{C}$ until further processing.

2.5.1 Single-labeling immunohistochemistry. After washing off the cryoprotectant solution, immunohistochemical processing was performed on a 1 in 6 series of free floating sections using the streptavidin-biotin-immunoperoxidase technique (Konsman and Blomqvist 2005). Briefly, non-specific binding sites were blocked by a $1 \mathrm{~h}$ incubation of sections in PBS, $\mathrm{pH}$ 7.4, containing $0.3 \%$ Triton X-100 and $1.0 \%$ bovine albumin. Commercially available rabbit antisera directed against a peptide at the N-terminus of c-Fos human origin (Cat. $\mathrm{n}^{\circ}$ : sc-52; Santa Cruz Biotechnology, Santa Cruz, CA; diluted 1:2000 in the same buffer) or against purified pseudorabies virus-Bartha (Cat $\mathrm{n}^{\circ}$ : PA1-081; Affinity BioReagents, Thermo Electron, Courtaboeuf, France; diluted 1:500 in the same buffer) or a mouse antibody raised against recombinant rat mGluR1alpha (Cat. $\mathrm{n}^{\circ}$ : 556331, Clone G209-488, BD Pharmingen, 
BD France, Le Point de Claix, France; diluted 1:1000 in the same buffer) were added to the sections overnight at room temperature or for $60 \mathrm{~h}$ at $4{ }^{\circ} \mathrm{C}$.

The c-Fos antiserum 1) has been characterized by the vendor to recognize a $62 \mathrm{kDa}$ protein, corresponding to the molecular weight of c-Fos, on Western blots, and 2) has previously been used by us (Konsman and Blomqvist 2005) and others (Engler et al. 2011; Farzi et al. 2015) at comparable dilutions in streptavidin-biotin-immunoperoxidase immunohistochemistry protocols on formaldehyde-fixed rat brain tissue.

The PRV-Ba antiserum has been shown by the vendor 1) to detect proteins on Western blots in the range of $80-155 \mathrm{kDa}$ representing various PRV proteins, 2) to result in immunohistochemical staining of the suprachiasmatic nucleus of the hypothalamus after PRV injection into vitreous body of the eye and 3) has already been used by us under conditions that are comparable to those used here (Yoshida et al. 2003).

The mGluR1alpha antibody has been characterized by the vendor 1) to recognize a $130 \mathrm{kDa}$ protein, corresponding to the molecular weight of mGluR1alpha, on Western blots, and 2) to yield immunohistochemical staining of Purkinje cells in formaldehyde-fixed rat cerebellum, where mGluR1alpha mRNA is strongly expressed (Berthele et al. 1998), which can be abolished by pre-incubation of the antibody with rat recombinant mGluR1alpha. In addition, 3) cellular surface staining with his antibody has been shown to decrease after mGluR1alpha agonist-induced receptor internalization (Hong et al. 2009).

After four rinses in PBS, sections were treated for $30 \mathrm{~min}$ in $0.3 \%(\mathrm{v} / \mathrm{v})$ hydrogen peroxide followed by rinses in PBS. Sections were incubated for $2 \mathrm{~h}$ at room temperature with biotinylated donkey anti-rabbit IgG (Amersham, Les Ulis, France) diluted 1:1000 in PBS containing $0.3 \%$ Triton $\mathrm{X}-100$ and $1.0 \%$ bovine albumin and stained using the $\mathrm{ABC}$ protocol (Vectastain Elite, Vector Laboratories, Eurobio/Abcys, Les Ullis, France) with nickelenhanced diaminobenzidine as a chromogene. 
Stained sections were examined with a microscope (Leica DM5500B, Leica Microsystems, Wetzlar, Germany) and images were captured by a high-resolution CCD video camera image and fed into a personal computer. Photomicrographs to illustrate c-Fos labeling were obtained using this system and saved as TIFF files. Image $\mathbf{J}$ software (http://rsbweb.nih.gov/ij/) was used to generate a digitized signal proportional to the intensity of illumination. Image processing was performed on the grey image by defining a set threshold for grey value and surface above which labeling had to be taken into account. C-Fos expression in a structure was first determined with an inclusive threshold allowing for the estimation the total number of labeled cells unilaterally per section. In case a significant effect of glutamate receptor antagonism was found, a second more restrictive threshold was applied to determine if the same treatment also altered the number of intensely-stained c-Fos-positive cells as well. After application of the threshold, the image was converted to a binary image and measurements made.

Since the PB and RM have been proposed to be part of a brainstem circuit involving the NTS that inhibits food intake (Morton et al. 2014), the number of c-Fos-positive cells were counted in these brainstem structures. To do so, for each animal, at least 3 sections were analyzed for the parabrachial nuclei (between bregma -8.60 and $-9.50 \mathrm{~mm}$ ) and a minimum of four sections for the raphé magnus (between bregma -9.25 and $-11.10 \mathrm{~mm}$ ). The NTS is a rostrocaudal long nucleus and receives sensory input in a loosely viscerotopically segregated manner along this axis and is therefore typically studied distinguishing 1) its part rostral to the AP, 2) the part at the level of the AP and 3) that caudal of the AP (Loewy 1990; Jean 1991). Thus, for each animal the number of c-Fos-immunoreactive cells in the "visceral" NTS were counted in at least 4 sections caudal to the AP (between bregma -14.36 and $-14.86 \mathrm{~mm}$ ), in a minimum of 2 sections at the level of the AP (between bregma -13.76 and $-14.16 \mathrm{~mm}$ ) known to receive visceral afferents and to display c-Fos induction in response to inflammatory 
signals (Rinaman 2011), and in no less than 3 sections rostral to the AP (between bregma 13.15 and $-13.60 \mathrm{~mm}$ ) where catecholaminergic neurons have been shown to specifically express c-Fos after peripheral LPS administration as compared to the consumption of a liquid palatable meal (Gaykema et al. 2009). In addition, the number of c-Fos-positive cells was quantified in at least 2 sections of the AP for every animal. Finally, to assess the effect of i4v administration of glutamate receptor antagonists on forebrain activation, c-Fos expression was quantified in at least 4 sections of the paraventricular nucleus of the hypothalamus (between bregma -1.33 and $-1.78 \mathrm{~mm}$ ), a structure well known to show robust c-Fos induction after peripheral LPS administration (Sagar et al. 1995; Konsman et al. 1999).

2.5.2 Double-labeling immunohistochemistry. To determine if neurons that are part of the brainstem network innervating the greater curvature of the stomach or those activated after ip LPS administration express glutamate receptor types found to influence food intake, doublelabeling immunohistochemistry was performed to detect the presence of pseudorabies virus or c-Fos and glutamate receptor subtypes. For this purpose a mouse antibody recognizing rat mGluR1-alpha (Cat. n: 556331, Clone G209-488, BD Pharmingen, BD France, Le Point de Claix, France) or mGluR2 (Cat. $n^{\circ}:$ ab15672, Abcam, Paris, France), the main mGluRs present on cell bodies throughout the dorsal vagal complex that comprises the NTS, AP and DMV (Hay et al. 1999), was used in combination with the pseudorabies virus-specific rabbit antiserum (Cat. n: PA1-081, Affinity BioReagents, Thermo Electron, Courtaboeuf, France) or the c-Fos-specific antiserum (Cat. $\mathrm{n}^{\circ}$ : sc-52, Santa Cruz Biotechnology, Santa Cruz, CA), all diluted 1:500 in PBS containing 0.3\% Triton X-100 and $1.0 \%$ bovine albumin and added to the sections for $60 \mathrm{~h}$ at $4{ }^{\circ} \mathrm{C}$ after washing off the cryoprotectant solution. After four washes in PBS, sections were incubated for $2 \mathrm{~h}$ at room temperature with biotinylated horse anti-mouse IgG (Vectashield, Vector Laboratories, Eurobio/Abcys, Les Ullis, France) diluted 1:250 in PBS containing $0.3 \%$ Triton X-100 and $1.0 \%$ bovine albumin. After washes in PBS, 
Avidin-Alexa 488 and Donkey anti-rabbit IgG-Alexa 546 or Avidin-Alexa 594 and Goat antirabbit IgG-Alexa 488 (Invitrogen, Leiden, the Netherlands), all diluted in 1:250 in PBS, were added to sections for $2 \mathrm{~h}$. Sections were then mounted in the dark and coverslipped with antifading mounting medium containing 4',6-diamidino-2-phenylindole (DAPI) (Vectashield, Vector Laboratories, Eurobio/Abcys, Les Ullis, France).

Sections were examined on an epifluorescent microscope equipped (Leica DM5500B, Leica Microsystems, Wetzlar, Germany) and on a confocal microscope (Leica SP5, Leica Microsystems, Wetzlar, Germany). Images from channels corresponding to DAPI, Alexa 488, 546 or 594 were obtained with a $1 \mu \mathrm{m}$ z-step and reconstituted as stacks in MetaMorph (Molecular Devices, Sunnyvale, CA, USA). The occurrence of double-labeled neurons was examined on stacks obtained by confocal microscopy with help of the Overlay and Montage functions. For illustrative purposes, stacks of the individual channels underwent a best focus operation in Image J. Image editing software (Adobe Photoshop, Adobe Systems, San Jose, CA) was used to adjust contrast and brightness only and to prepare microphotographs.

\subsection{Data presentation and analysis}

The experiments designated for c-Fos immunohistochemistry after i4v glutamate receptor antagonism and ip LPS administration and those aimed at comparing the effects of i4v glutamate receptor antagonism between ip LPS and ip IL-1beta were expected to yield similar effects on food intake and changes in body weight. When there were no significant differences in terms of food intake or body weight between experiments addressing the effects of a glutamate receptor antagonist, that is when the different experiments were entered as an independent variable or factor, data obtained after ip injection of LPS or its vehicle were pooled and analyzed accordingly.

All data are reported as means \pm SEM. Cumulative food intake and changes in body weight (0-4 h; 0-6 h and 2-6 h) after ip injection were analyzed by a two-way ANOVA using i4v and 
ip treatments as between factors and represented in figures. Food intake and changes in body weight over consecutive $2 \mathrm{~h}$ time windows were analyzed by a two-way ANOVA using i4v and ip treatments as between factors and time as a within factor and provided as supplementary tables. The unilateral mean number of c-Fos-positive nuclei per brainstem section was analyzed by a two-way ANOVA with i4v and ip treatments as between factors. Significant effects were further analyzed by the Newman-Keuls post-hoc test. In all cases, a level of $\mathrm{p}<0.05$ was considered as statistically significant. 


\section{Results}

\subsection{I4v AMPA receptor antagonism exacerbated ip LPS-induced weight loss}

Food intake. A two-way ANOVA on cumulated food intake revealed a significant anorectic effect of LPS ( $\left.\mathrm{F}_{1,42}: 0-4 \mathrm{~h}: 22.0, \mathrm{p}<0.001 ; 0-6 \mathrm{~h}: 49.5, \mathrm{p}<0.001 ; 2-6 \mathrm{~h}: 59.3, \mathrm{p}<0.001\right)$ as well as a significant interaction between CNQX and LPS treatments $\left(\mathrm{F}_{1,42}: 2-6 \mathrm{~h}: 4.67, \mathrm{p}<0.05\right)$. Post-hoc tests, however, did not show a significant effect of i4v CNQX on ip LPS-induced hypophagia (Figure 1A). A similar ANOVA also indicated a significant hypophagic effect of IL-1beta ( $\mathrm{F}_{1,24}: 0-4$ h: 22.4, $\left.\mathrm{p}<0.001 ; 0-6 \mathrm{h:} \mathrm{38.8,} \mathrm{p}<0.001 ; 2-6 \mathrm{h:} 39.5, \mathrm{p}<0.001\right)$ as well as a significant food intake-reducing effect of CNQX ( $\left.\mathrm{F}_{1,24}: 2-6 \mathrm{~h}: 4.64, \mathrm{p}<0.05\right)$, but no interaction between treatments (Figure 1B).

Body weight. A two-way ANOVA on cumulative changes in body weight showed a significant reduction in body weight after LPS $\left(\mathrm{F}_{1,44}: 0-4 \mathrm{~h}: 39.5, \mathrm{p}<0.001 ; 0-6 \mathrm{~h}: 54.4\right.$, $\mathrm{p}<0.001 ; 2-6$ h: 61.0, $\mathrm{p}<0.001)$ and after CNQX $\left(\mathrm{F}_{1,44}: 0-4 \mathrm{~h}: 5.07, \mathrm{p}<0.05\right)$ as well as a tendency for an interaction between CNQX and LPS treatments $\left(\mathrm{F}_{1,44}: 0-6 \mathrm{~h}: 3.29, \mathrm{p}=0.077\right.$; 2-6 h: 2.97, p<0.092). Post-hoc tests indicated that i4v CNQX exacerbated ip LPS-induced weight loss over the $6 \mathrm{~h}$ after the experiment ( $\mathrm{p}<0.05$; Figure 1C). A two-way ANOVA on cumulated changes in body weight showed a significant loss of body weight after IL-1beta injection ( $\mathrm{F}_{1,24}: 0-4$ h: 31.9, $\left.\mathrm{p}<0.001 ; 0-6 \mathrm{~h}: 36.5, \mathrm{p}<0.001 ; 2-6 \mathrm{~h}: 32.7, \mathrm{p}<0.001\right)$, but no significant effect of CNQX or interaction between treatments (Figure 1D).

Effects of i4v CNQX and ip LPS and ip IL-beta on food intake and body weight changes during consecutive $2 \mathrm{~h}$ periods are provided in supplementary tables 1 and 2, respectively.

Since circulating corticosterone levels modulate weight loss after LPS administration (Johnson et al. 1996), its plasma concentrations were measured after i4v AMPA/kainate receptor antagonism and ip LPS administration. A two-way ANOVA on plasma corticosterone concentrations, determined by radioimmunoassay (Konsman et al. 2008), 
revealed a significant increase after LPS injection $\left(\mathrm{F}_{1,24}: 10.6, \mathrm{p}<0.01\right)$, but no effect of $i 4 \mathrm{v}$ CNQX administration or interaction between CNQX and LPS treatments (Figure 3A). As weight loss after LPS administration is likely to be mediated in part by the peripheral actions of pro-inflammatory cytokines, circulating IL-1beta concentrations were also analyzed after i4v AMPA/kainate receptor antagonism and ip LPS administration. A two-way ANOVA on plasma IL-1beta, measured by enzyme-linked immunosorbent assay (Konsman et al. 2008), showed a significant rise after LPS injection $\left(\mathrm{F}_{1,22}: 7.84, \mathrm{p}<0.05\right)$ as well as a significant interaction between CNQX and LPS treatments $\left(\mathrm{F}_{1,22}: 31.9, \mathrm{p}<0.05\right)$. Post-hoc tests indicated that i4v CNQX significantly attenuated the ip LPS-induced increase in circulating IL-1beta concentrations $(\mathrm{p}<0.05$; Figure $3 \mathrm{~B})$.

\section{$3.2 \mathrm{I} 4 \mathrm{v}$ metabotropic glutamate receptor antagonism increased spontaneous food intake}

Food intake. A two-way ANOVA on cumulated food intake indicated a significant reduction after LPS injection $\left(\mathrm{F}_{1,95}: 0-4 \mathrm{~h}: 36.0, \mathrm{p}<0.001 ; 0-6 \mathrm{~h}: 54.3, \mathrm{p}<0.001 ; 2-6 \mathrm{~h}: 30.0\right.$, $\mathrm{p}<0.001)$ and a significant increase after AP3 administration $\left(\mathrm{F}_{1,95}: 0-4 \mathrm{~h}: 11.6, \mathrm{p}<0.001 ; 0-6\right.$ h: 10.3, $\mathrm{p}<0.01$ ), but no significant interaction between treatments (Figure 3A). The same analysis also showed a food intake-reducing effect of IL-1beta $\left(\mathrm{F}_{1,57}: 0-4 \mathrm{~h}: 56.2, \mathrm{p}<0.001 ; 0\right.$ 6 h: 102 , p<0.001; 2-6 h: 26.1, p<0.001) and a tendency for an interaction between ip and i4v treatments $\left(\mathrm{F}_{1,57}: 0-4 \mathrm{~h}: 3.91, \mathrm{p}=0.053\right)$. Post-hoc tests indicated that $\mathrm{i} 4 \mathrm{v}$ AP3 increased food intake between 0 and $4 \mathrm{~h}$ in animals injected ip with saline $(\mathrm{p}<0.05)$, but not in those administered IL-1beta (Figure 3B).

Body weight. A two-way ANOVA on cumulated changes in body weight showed significant weight loss after LPS ( $\mathrm{F}_{1,95}: 0-4 \mathrm{~h}: 46.8$, $\mathrm{p}<0.001 ; 0-6 \mathrm{~h}: 51.7, \mathrm{p}<0.001 ; 2-6 \mathrm{~h}$ : 30.4, p<0.001), but no significant effect of AP3 either globally or in interaction with LPS (Figure 3C). The same analysis also revealed significant weight loss after IL-1beta injection $\left(\mathrm{F}_{1,57}: 0-4 \mathrm{~h}: 40.6, \mathrm{p}<0.001 ; 0-6 \mathrm{~h}: 28.2, \mathrm{p}<0.001\right)$, no significant main effect of AP3, but a 
tendency for an interaction between ip and i4v treatments $\left(\mathrm{F}_{1,57}: 0-4 \mathrm{~h}: 3.56, \mathrm{p}=0.064\right)$. Posthoc tests did however not show a significant effect of i4v AP3 on changes in body weight after ip saline or IL-1beta administration (Figure 3D).

Effects of i4v AP3 and ip LPS and ip IL-beta on food intake and body weight changes during consecutive $2 \mathrm{~h}$ periods are provided in supplementary tables 3 and 4, respectively.

\subsection{Brainstem distribution of mGluRl-alpha-immunoreactivity}

Given that i4v administration of the group I and II mGluR antagonist AP3 resulted in a robust increase in food intake, its potential brainstem sites of action were studied next. Since determining the effect of mGluR antagonism on c-Fos expression was one of the objectives of the present work and group I mGluR stimulation is known to induce c-Fos (Wang 1998), efforts were focused on mGluR1. mGluR1alpha-immunoreactivity was therefore assessed in eight randomly-chosen animals from the groups that received i4v PBS and either ip saline or LPS.

In accordance with previous studies using the same and other antibodies, strong mGluR1alpha-immunoreactive labeling was observed in Purkinje cells of the cerebellum (Fotuhi et al. 1993; Hong et al. 2009). In addition, the motor nucleus of trigeminal nerve (V: Figure 4B, C), the facial nucleus, spinal nucleus of the trigeminal (SPV; Figure 4E, F, H, I) and hypoglossal nucleus (XII; Figure 4E, F, H, I) also contained many strongly mGluR1alpha-immunopositive neuronal cell bodies. In the ventrolateral medulla caudal to the facial nucleus from the paragigantocellular to the lateral reticular nucleus (GRN and LRN in Figure 4E, F, H, I). Robust mGluR1alpa-immunoreactivity was also found in a more scattered way in neurons throughout the pontine reticular nucleus between the trigeminal motor nucleus and the RM (Figure 4B). In the dorsolateral brainstem, the dorsal cochlear nucleus showed immunopositive cells in its outer layers and strongly stained cellular processes, whereas more rostrally the PB displayed only light immunoreactive processes. In the dorsocaudal brainstem, 
cell bodies of neurons in the DMV showed light mGluR1alpha-immunoreactivity (Figure 4I). A few lightly stained mGluR1alpha-immunopositive cells were found in the dorsolateral NTS even though numerous weakly labeled immunoreactive processes were observed throughout this structure.

$3.4 \mathrm{I} 4 \mathrm{v}$ metabotropic glutamate receptor antagonism attenuated c-Fos expression in the lateral $P B$ and in the NTS rostral to the AP after ip LPS administration

In view of the stimulating effect of $i 4 \mathrm{v}$ administration of the mGluR group I and II receptor antagonist AP3 on food intake, c-Fos expression was assessed in brainstem structures. The first experiment designated for c-Fos immunohistochemistry after $\mathrm{i} 4 \mathrm{v}$ mGluR receptor antagonism and ip LPS administration only resulted in a statistical trend concerning the stimulating effect of $\mathrm{i} 4 \mathrm{v}$ group I and II mGluR antagonism on food intake. The experiment was therefore repeated and found to yield a significant positive effect of $i 4 \mathrm{v}$ mGluR antagonism on food intake. It is this second experiment that was therefore used for the study of c-Fos expression in the brain.

In the NTS caudal to the AP, a two-way ANOVA revealed a trend for ip LPS to increase the number of c-Fos-immunoreactive cells $\left(\mathrm{F}_{1,27}: 3.43, \mathrm{p}=0.075\right)$, but no effect of $\mathrm{i} 4 \mathrm{v}$ AP3 or interaction between treatments (Table 1). In the NTS at the level of the AP, the same analysis showed that ip LPS significantly increased the number of c-Fos-immunoreactive cells $\left(\mathrm{F}_{1,25}\right.$ : 12.0, $\mathrm{p}<0.01$ ), but did not indicate any effect of i4v AP3 or interaction between treatments (Table 1). In the AP itself, the same analysis revealed a significant rise in the number of cFos-immunoreactive cells after ip LPS injection $\left(\mathrm{F}_{1,27}: 11.6, \mathrm{p}<0.001\right)$, but did neither show an effect of i4v AP3 nor an interaction between treatments (Table 1).

In the NTS rostral to the AP, a two-way ANOVA on c-Fos expression showed a significant increase after ip LPS treatment $\left(\mathrm{F}_{1,32}: 6.18, \mathrm{p}<0.05\right)$ and a trend for an interaction between AP3 and LPS treatments $\left(\mathrm{F}_{1,32}: 3.44, \mathrm{p}=0.0730\right)$. Post-hoc tests indicated that $\mathrm{i} 4 \mathrm{v}$ AP3 
reduced ip LPS-induced c-Fos expression at this level of the NTS $(\mathrm{p}<0.05$; Figure 5A and CF). When the analysis was done with the more stringent threshold, LPS was still found to increase the number of $\mathrm{c}$-Fos-immunoreactive cells $\left(\mathrm{F}_{1,32}: 4.96, \mathrm{p}<0.05\right)$, but no interaction between treatments was observed (Data not shown). In view of the presence of light mGluR1alpha-immunoreactivity in cell bodies of the rostral NTS (Hay et al. 1999), double-labeling experiments were undertaken to determine if LPS-induced c-Fos expression in the NTS rostral to the AP occurred in mGluR1-positive cells. In three animals with robust ip LPSinduced c-Fos expression, confocal microscopy analysis showed that the areas of mGluR1 and c-Fos expression in the NTS rostral to the AP were found mostly to not overlap with mGluR1 being present predominantly lateral from the median aperture-choroidal fissure and c-Fos being concentrated largely more medially (Figure 5G and H). However, even in the small area of overlap between mGluR1 and c-Fos double-labeled cells were never encountered (Figure $5 \mathrm{~J})$.

In the lateral PB, a two-way ANOVA revealed a significant increase in the number of cFos-immunoreactive cells after ip LPS injection $\left(\mathrm{F}_{1,20}: 9.84, \mathrm{p}<0.01\right)$ and a significant decrease in c-Fos-positive nuclei subsequent to i4v AP3 administration $\left(\mathrm{F}_{1,20}: 10.2 ; \mathrm{p}<0.01\right)$, but no interaction between treatments (Figure 5B). When the analysis was repeated with the more stringent threshold, LPS still increased $\left(\mathrm{F}_{1,20}: 12.3, \mathrm{p}<0.01\right)$, while AP3 again decreased $\left(\mathrm{F}_{1,20}: 8.65 ; \mathrm{p}<0.01\right)$, the number of $\mathrm{c}-\mathrm{Fos}-\mathrm{immunoreactive} \mathrm{cells} \mathrm{in} \mathrm{the} \mathrm{lateral} \mathrm{PB.} \mathrm{Double-}$ labeling experiments were performed to determine if c-Fos expression in the lateral PB occurred in mGluR1-positive cells. Even though c-Fos and mGluR1 expression occurred in the same area of the PB, no double labeled cells were observed in this structure in three animals with robust ip LPS-induced c-Fos expression (Data not shown).

Since double labeling experiments indicated the presence of PRV-Ba- and mGluR1alphadouble-labeled neurons in the RM, the number of c-Fos-immunoreactive cells was also 
analyzed in this structure. A two-way ANOVA did not show any effect of treatments or interaction between treatments on c-Fos expression in the RM (Table 1). Finally, to assess the effect of $i 4 \mathrm{v}$ administration of the mGluR receptor antagonist on forebrain activation, c-Fos expression was analyzed in the paraventricular nucleus of the hypothalamus. In this structure, a two-way ANOVA indicated a significant increase in the number of c-Fos-immunoreactive cells after ip LPS $\left(\mathrm{F}_{1,30}: 5.81, \mathrm{p}<0.05\right)$, but no effect of $\mathrm{i} 4 \mathrm{v}$ AP3 or interaction between treatments (Table 1).

Given that AMPA/kainate receptors are strongly expressed in the AP and in the NTS at the interface with and level of the AP and itself (Kessler and Baude 1999), c-Fos-immunopositive cells were also counted in these structures after i4v administration of CNQX. In the NTS at the level of the AP, a two-way ANOVA showed that ip LPS significantly increased the number of c-Fos-immunoreactive cells $\left(\mathrm{F}_{1,23}: 14.2, \mathrm{p}<0.01\right)$, but did not reveal any effect of CNQX or interaction between treatments (Data not shown). In the AP itself, the same analysis revealed a significant rise in the number of c-Fos-immunoreactive cells after ip LPS injection $\left(F_{1,23}: 11.6, p<0.01\right)$, but did neither show an effect of i4v CNQX nor an interaction between treatments (Data not shown).

\section{5 mGluR expression in the brainstem network innervating the stomach}

Four out of the six animals that were allowed to survive 96-102 h after neurotropic virus injection showed robust labeling throughout the NTS and in addition to the DMV (Figure 6B, $\mathrm{D}, \mathrm{F}, \mathrm{H}, \mathrm{J}$ and $\mathrm{L}$ ). In addition, brainstem PRV-Ba immunoreactive neurons were found in the lateral $\mathrm{PB}$, the pontine reticular nucleus and the rostral RM (Figure 7B, D and F). Animals that had been subject to intragastric injection of PRV-Ba showed the same brainstem distribution of mGluR1alpha-immunoreactivity with strongly labeled neurons being concentrated in the trigeminal motor nucleus and the hypoglossal nucleus (Figure 6A, C, E 
and G), robust and more scattered cells being present in the pontine reticular nucleus and RM (Figure 7A, C) and weaker staining occurring in the dorsal vagal complex.

Epifluorescent examination of combined immunohistochemistry for PRV-Ba and mGluRlalpha resulted in less mGluRlalpha-immunoreactive-like signal in all regions examined compared to diaminobenzidine-peroxidase staining. Neurons of the hypoglossal nucleus (XII) could still be distinguished (Figure 6I, K), but for example cell bodies and processes in the RM were only weakly stained (Figure 7E). In contrast, PRVimmunoreactivity was readily detected using epifluorescence (Figure 6J, L and Figure 7F). Confocal analysis of brainstem structures resulted in a signal-to-noise ratio comparable to peroxidase-based staining of mGluR1alpha, but did not reveal any double labeled cells in the NTS and DMV, even though the former two contained numerous single-labeled cells (Figure 6M-O). In the parabrachial nuclei PRV-Ba- and mGluR1alpha-like immunoreactivity never occurred in the same neurons (not shown). However, double-labeled neurons (max 3 per section) were found to be present in the rostroventral part of the RM (Figure 7G, H, I-K).

Although mGluR2-immunoreactive cellular processes were frequently observed in the dorsal and central area postrema, no double labeling with PRV-Ba and mGluR2 was observed (Data not shown). 


\section{Discussion}

In the present work, we studied the role of brainstem glutamate receptors in the regulation of food intake in healthy animals and in sickness-associated hypophagia brought about by peripheral LPS or IL-1beta administration. Its main findings are that brainstem group I and II mGluR antagonism increased food intake both in saline- and LPS-, but not IL-1beta-, treated rats and that it reduced the number of c-Fos-positive cells in the lateral PB and LPS-induced c-Fos expression $n$ the NTS rostral to the AP. Group I mGluRs were found to be absent from NTS and PB c-Fos-positive cells or neurons that are part of the network innervating the stomach, but present on RM neurons regulating gastric function as well as on neurons of the trigeminal motor and hypoglossal nuclei.

In the different series of experiments addressing the effects of $\mathrm{i} 4 \mathrm{v}$ ionotropic or metabotropic glutamate receptor antagonism, control animals were found to eat between 5 and $10 \mathrm{~g}$ of food over the total period of $6 \mathrm{~h}$ comprising the last hour(s) of the light phase and the first hours of the dark phase when rats are most prone to spontaneously feed. This variability between series of experiments can be explained by the fact that, when given ad libitum access to food, each rat has its own meal pattern, which is mostly repeated from day to day (van Dijk and Strubbe 2003). The rationale to study the effects of brainstem glutamate and systemic inflammatory stimuli in spontaneously-feeding animals with ad libitum access to regular chow was based on the finding that food restriction prior to administration of bacterial LPS has been shown to affect subsequent hypophagia and weight loss (MacDonald et al. 2014).

In accordance with previous studies using comparable doses of LPS or IL-1beta (Anforth et al. 1998; Konsman et al. 2008), animals injected with these molecules displayed signs of sickness behavior with reduced food intake and locomotion. Interestingly, animals injected with a comparable dose of LPS continue to hoard food pellets when environmental conditions favor this behavior, but do not consume those (Aubert et al. 1997). Thus, hypophagia is not 
merely a consequence of reduced locomotion or muscle weakness, but rather due to a changed motivation to consume and therefore of interest to study with functional neuroanatomical approaches.

Previous work has shown that administration of an AMPA receptor into the fourth ventricle (i4v) decreases sucrose consumption and to a lesser extent deprivation-induced chow intake (Zheng et al. 2002). We observed that an AMPA/kainate receptor antagonist given i4v one hour (as in the IL-1beta experiment), but not two hours (as in the LPS experiment), before the start of the dark phase reduced subsequent chow intake during the first hours of the dark phase in rats that with ad libitum access to food that were injected ip with vehicle. Thus, brainstem AMPA/kainate receptors seem to play a role in stimulating food intake when the motivation to consume food is high.

Given that central ionotropic and metabotropic glutamate receptors play part in the inhibition of gastric acid secretion and orofacial allodynia after peripheral LPS or IL-1beta administration, respectively (Garcia-Zaragoza et al. 2000; Jung et al. 2006), we set out to study if brainstem glutamate receptors are involved in the reduction of food intake induced by these inflammatory stimuli. Brainstem AMPA/kainate receptor antagonism aggravated LPSinduced weight loss without significantly affecting food intake. Altered activation of the hypothalamo-pituitary-adrenal (HPA) axis may explain this finding. Indeed, HPA-axis activation resulting in increased circulating corticosterone levels modulates weight loss after LPS administration (Johnson et al. 1996). Moreover, under inflammatory conditions the NTS and AP are important for activation of the paraventricular nucleus of the hypothalamus that controls HPA axis activity (Lee et al. 1998; Marvel et al. 2004). However, our findings that AMPA/kainate receptor antagonism did neither modify expression of the cellular activation marker c-Fos in these brainstem structures nor affect circulating corticosterone levels argue against the possibility that caudal brainstem-dependent HPA-activation would modulate LPS- 
associated body weight loss. Alternatively, inhibition of anti-inflammatory vago-vagal reflexes by NTS or DMV action of the AMPA/kainate receptor antagonist, resulting in higher peripheral concentration of pro-inflammatory cytokines, may explain why its $\mathrm{i} 4 \mathrm{v}$ administration exacerbated LPS-induced weight loss. Indeed, stimulation of vagal efferents has been shown to inhibit LPS-induced systemic pro-inflammatory cytokine production (Borovikova et al. 2000). However, our finding that brainstem AMPA/kainate receptor antagonism reduced rather than increased ip LPS-induced circulating IL-1beta concentrations does not corroborate the hypothesis that brainstem AMPA/kainate glutamate receptors in antiinflammatory vago-vagal circuits inhibit systemic inflammation.

To the best of our knowledge the present findings are the first to indicate a role for brainstem mGluRs in inhibiting food intake. Previous work has established that while peripheral administration of a group I mGluR5 antagonist inhibits deprivation-induced food intake (Bradbury et al. 2005), peripheral injection of a group I and II mGluR antagonist has no effect on food intake in healthy animals making a fixed number of nose pokes to obtain food (Weiland et al. 2006). The mGluR antagonist used in the latter study did, however, increase food intake in hypophagic animals rendered sick by peripheral LPS administration. As the extent to which this antagonist penetrates the nervous system is unknown and mGluRs are present both on peripheral nerves and in the brain (Walker et al. 2001; Page et al. 2005; Slattery et al. 2006; Young et al. 2007; Lindstrom et al. 2008), we administered the same mGluR antagonist into the $4 \mathrm{v}$ to study if brainstem mGluRs play a role in the regulation of spontaneous food intake and sickness-associated hypophagia. We showed that brainstem mGluR antagonism increased food intake both in animals that received an ip saline injection and in animals rendered sick by ip LPS, but not by ip IL-1beta, administration, suggesting that brainstem glutamate action on mGluRs inhibits spontaneous feeding. 
Our finding that brainstem mGluR antagonism attenuated LPS- but not IL-1beta-induced hypophagia may be explained by IL-1beta action on the hypothalamus where the arcuate nucleus expresses IL-1 receptors (Ericsson et al. 1995). The extent to which the arcuate hypothalamus mediates the rapid anorectic effects of IL-1beta remains however to be established. Indeed, neonatal excitotoxic lesions of the majority of neuropeptide Y/Agoutirelated protein and proopiomelanocortin arcuate neurons and interruption of arcuate projections to the paraventricular and lateral hypothalamus exacerbate, rather than attenuate, IL-1beta-induced hypophagia during the first hours after food deprivation (Reyes and Sawchenko 2002). However, it was subsequently established that only part of the arcuate neuropeptide Y/Agouti-related protein-containing neurons and none of the proopiomelanocortin-expressing neurons express IL-1 receptors (Scarlett et al. 2008) (Chaskiel et al., unpublished observations). The latter finding renders the interpretation of the effects of lesioning the majority of arcuate neuronal cell bodies or their projections with respect to the role of arcuate IL-1 receptors in IL-1beta-induced anorexia less straightforward. Finally, and although proopiomelanocortin arcuate neurons do not express IL-1 receptors, central melanocortin antagonism does alleviate hypophagia from $8 \mathrm{~h}$ onwards after the peripheral administration of either IL-1beta or LPS (Huang et al. 1999; Whitaker and Reyes 2008). The role of arcuate IL-1 receptors in IL-1-induced anorexia remains therefore to be determined.

Since group I mGluR stimulation induces the cellular activation marker c-Fos (Wang 1998), we focused our neuroanatomical analyses on mGluR1 and c-Fos. The mGluR1alphaimmunoreactivity observed in the present work was in accordance with that of previous studies addressing its expression either in the rostral or caudal brainstem (Fotuhi et al. 1993; Petralia et al. 1997; Hay et al. 1999). Based on our observations throughout its rostrocaudal length, a more general pattern of mGluR1alpha expression in facial nerve motor neurons of 
the brainstem emerged. However, with the context of food intake in mind, we focused on strongly labeled neurons in the trigeminal motor nucleus and hypoglossal nucleus and to a lesser extent in the RM. In other brainstem nuclei structures relevant for the regulation of food intake mGluR1 expression was weaker with the NTS containing scattered immunoreactive neurons in addition to processes and the PB only displaying weak labeling of fibers.

Many stimuli known to reduce food intake result in c-Fos expression in the NTS and PB (Rinaman 2011; Carter et al. 2013). We observed that mGluR brainstem antagonism reduced c-Fos in the lateral PB both in saline- and LPS-treated rats and that this effect concerned both the total number of as well as the most-intensely stained c-Fos-immunoreactive cells. These findings suggest that activation of this structure is highly relevant to the overall anorexigenic effect of endogenous mGluR activation. CGRP neurons in the lateral PB nucleus are known to express c-Fos after LPS expression (Paues et al. 2001). Interestingly, inhibition of these neurons alleviates LPS-induced hypophagia but also increases food intake in the absence of sickness (Carter et al. 2013). Since group II mGluR antagonism alone leads to robust c-Fos expression in the PB (Hetzenauer et al. 2008), it seems highly unlikely that activation of endogenous group II mGluRs played a role in activation of the PB in our freely-feeding animals regardless of whether or not they were sick. Our observation that c-Fos and mGluR1 did not colocalize in the PB suggests that the anorexigenic effect of endogenous brainstem mGluR stimulation does not involve metabotropic glutamate action on c-Fos-expressing neuronal cell bodies of the lateral PB. However, mGluR1-immunoreactivity in the PB is mainly observed on presumed dendritic profiles, even though the external lateral and internal lateral PB are largely immunonegative (Guthmann and Herbert 1999). But since some neurons in the lateral PB have dendrites that travel across subnuclei (Herbert and BellintaniGuardia 1995), it is possible that glumate action through mGluR1s present on these dendrites would result in c-Fos expression in the lateral PB. 
We found that $\mathrm{i} 4 \mathrm{v}$ administration of the group I and II mGluR antagonist specifically reduced ip LPS-induced c-Fos expression in the rostral NTS. Even though LPS administration, but not the consumption of a liquid palatable meal, results in activation of catecholaminergic neurons in the rostral NTS (Gaykema et al. 2009), an important part of these c-Fos-positive cells do not express catecholamines (Sagar et al. 1995; Hollis et al. 2005). Since catecholamines and group I mGluRs do not overlap in the NTS (Hay et al. 1999; Austgen et al. 2009), we assessed if LPS-induced c-Fos expression in the rostral NTS occurred in mGluR1-expressing neurons. Our observation that c-Fos and mGluR1 did not colocalize in the NTS indicates that the inhibiting effect of endogenous brainstem mGluR activation on food intake after LPS administration may be mediated by rostral NTS c-Fosexpressing neurons, but does not involve mGluR1 action on the cell bodies of these neurons.

The mGluR antagonist we used also blocks group II mGluRs (Cartmell and Schoepp 2000), which are expressed in the dorsal vagal complex (Hay et al. 1999). Interestingly, i4v application of a group II mGluR antagonist prior to oxytocin microinjection into the dorsal vagal complex results in increased gastric tone, whereas in the absence of mGluR blockade this neuropeptide invariably decreases gastric tone (Holmes et al. 2013). As oxytocin neurons in the paraventricular hypothalamus project to the dorsal vagal complex (Sawchenko and Swanson 1982) and express c-Fos after peripheral LPS injection (Sagar et al. 1995; Matsunaga et al. 2000), i4v administration of AP3 may have alleviated LPS-induced oxytocin-mediated gastric stasis and, in turn, have increased food intake.

Gastric motility is indeed important in the regulation of food intake (Rinaman et al. 1993). As an alternative approach to identify pathways mediating the inhibiting effect of brainstem mGluRs on food intake, we therefore determined if mGluRs are expressed by brainstem neurons that are part of the neuronal network controlling gastric motility. Double labeling for the neurotropic PRV-Ba injected into the stomach wall and mGluR1 resulted in several 
double-labeled neurons in the ventral RM. Interestingly, serotonergic RM neurons project to the rostral NTS and inhibit food intake (Wu et al. 2012). Although situated at several mm distance from the ventricular system, the ventral RM is close to the subarachnoid CSF containing-space downstream of the $4 \mathrm{v}$ from which molecules can reach the extracellular fluid of the adjacent parenchyma through paravascular spaces (Rennels et al. 1985). Thus, our findings can be interpreted to suggest that the food intake-promoting effect of mGluR antagonism may have occurred through blockade of glutamate action on mGluR1-expressing RM neurons that are part of the brainstem network innervating the stomach.

However, when considering this hypothesis, one should bear in mind that the RM did not express c-Fos. This may be explained by considering that RM c-Fos expression occurs after food restriction rather than after consumption (Takase and Nogueira 2008) and that our animals had free access to food. But one should also keep in mind that c-Fos is not a universal marker of neuronal activation (Curran and Morgan 1995). Indeed, neurons in the trigeminal motor and the hypoglossal nuclei that control jaw masticatory and tongue muscles, respectively (Fay and Norgren 1997a; Fay and Norgren 1997b) did not express c-Fos in the present study, but were most likely activated as animals consumed food during the early dark phase. Since many neurons in these nuclei were found to express mGluR1, we propose that blockade of glutamate action on these neurons may also have contributed to the food intakestimulating effect of brainstem mGluR antagonism.

In conclusion, our findings show that brainstem metabotropic glutamate receptors reduce food intake and activate the lateral PB as well as the rostral NTS after peripheral bacterial lipopolysaccharide administration, possibly through a group I mGluR1-dependent, but indirect, stimulation of projections between these two brainstem structures. 


\section{Acknowledgments}

We thank the staff of the Bordeaux Imaging Center for their help in using the confocal microscope. 


\section{References}

Anforth HR, Bluthe RM, Bristow A, Hopkins S, Lenczowski MJ, Luheshi G, Lundkvist J, Michaud B, Mistry Y, Van Dam AM, Zhen C, Dantzer R, Poole S, Rothwell NJ, Tilders FJ, Wollman EE (1998) Biological activity and brain actions of recombinant rat interleukin-1alpha and interleukin-1beta. Eur Cytokine Netw 9:279-288.

Aubert A, Kelley KW, Dantzer R (1997) Differential effect of lipopolysaccharide on food hoarding behavior and food consumption in rats. Brain Behavior and Immunity $11: 229-238$.

Austgen JR, Fong AY, Foley CM, Mueller PJ, Kline DD, Heesch CM, Hasser EM (2009) Expression of Group I metabotropic glutamate receptors on phenotypically different cells within the nucleus of the solitary tract in the rat. Neuroscience 159:701-716.

Berthele A, Laurie DJ, Platzer S, Zieglgansberger W, Tolle TR, Sommer B (1998) Differential expression of rat and human type I metabotropic glutamate receptor splice variant messenger RNAs. Neuroscience 85:733-749.

Bielavska E, Miksik I, Krivanek J (2000) Glutamate in the parabrachial nucleus of rats during conditioned taste aversion. Brain Res 887:413-417.

Borovikova LV, Ivanova S, Zhang M, Yang H, Botchkina GI, Watkins LR, Wang H, Abumrad N, Eaton JW, Tracey KJ (2000) Vagus nerve stimulation attenuates the systemic inflammatory response to endotoxin. Nature 405:458-462.

Bradbury MJ, Campbell U, Giracello D, Chapman D, King C, Tehrani L, Cosford ND, Anderson J, Varney MA, Strack AM (2005) Metabotropic glutamate receptor mGlu5 is a mediator of appetite and energy balance in rats and mice. J Pharmacol Exp Ther 313:395-402.

Carter ME, Soden ME, Zweifel LS, Palmiter RD (2013) Genetic identification of a neural circuit that suppresses appetite. Nature 503:111-114. 
Cartmell J, Schoepp DD (2000) Regulation of neurotransmitter release by metabotropic glutamate receptors. J Neurochem 75:889-907.

Cross-Mellor SK, Kavaliers M, Ossenkopp KP (2004) Comparing immune activation (lipopolysaccharide) and toxin (lithium chloride)-induced gustatory conditioning: lipopolysaccharide produces conditioned taste avoidance but not aversion. Behav Brain Res 148:11-19.

Curran T, Morgan JI (1995) Fos: an immediate-early transcription factor in neurons. Journal Of Neurobiology 26:403-412.

Dev KK, Petersen V, Honore T, Henley JM (1996) Pharmacology and regional distribution of the binding of 6-[3H]nitro-7-sulphamoylbenzo[f]-quinoxaline-2,3-dione to rat brain. J Neurochem 67:2609-2612.

Diaz-Casares A, Lopez-Gonzalez MV, Peinado-Aragones CA, Gonzalez-Baron S, DawidMilner MS (2012) Parabrachial complex glutamate receptors modulate the cardiorespiratory response evoked from hypothalamic defense area. Auton Neurosci 169:124-134.

Ek M, Kurosawa M, Lundeberg T, Ericsson A (1998) Activation of vagal afferents after intravenous injection of interleukin-1beta: role of endogenous prostaglandins. Journal of Neuroscience 18:9471-9479.

Engler H, Doenlen R, Engler A, Riether C, Prager G, Niemi MB, Pacheco-Lopez G, Krugel U, Schedlowski M (2011) Acute amygdaloid response to systemic inflammation. Brain Behav Immun 25:1384-1392.

Ericsson A, Liu C, Hart RP, Sawchenko PE (1995) Type 1 interleukin-1 receptor in the rat brain: distribution, regulation, and relationship to sites of IL-1-induced cellular activation. Journal of Comparative Neurology 361:681-698. 
Farzi A, Reichmann F, Meinitzer A, Mayerhofer R, Jain P, Hassan AM, Frohlich EE, Wagner K, Painsipp E, Rinner B, Holzer P (2015) Synergistic effects of NOD1 or NOD2 and TLR4 activation on mouse sickness behavior in relation to immune and brain activity markers. Brain Behav Immun 44:106-120.

Fay RA, Norgren R (1997a) Identification of rat brainstem multisynaptic connections to the oral motor nuclei using pseudorabies virus. I. Masticatory muscle motor systems. Brain Research. Brain Research Reviews 25:255-275.

Fay RA, Norgren R (1997b) Identification of rat brainstem multisynaptic connections to the oral motor nuclei using pseudorabies virus. III. Lingual muscle motor systems. Brain Res Brain Res Rev 25:291-311.

Fotuhi M, Sharp AH, Glatt CE, Hwang PM, von Krosigk M, Snyder SH, Dawson TM (1993) Differential localization of phosphoinositide-linked metabotropic glutamate receptor (mGluR1) and the inositol 1,4,5-trisphosphate receptor in rat brain. J Neurosci 13:2001-2012.

Garcia-Zaragoza E, Barrachina MD, Moreno L, Esplugues JV (2000) Role of central glutamate receptors, nitric oxide and soluble guanylyl cyclase in the inhibition by endotoxin of rat gastric acid secretion. Br J Pharmacol 130:1283-1288.

Gaykema RP, Daniels TE, Shapiro NJ, Thacker GC, Park SM, Goehler LE (2009) Immune challenge and satiety-related activation of both distinct and overlapping neuronal populations in the brainstem indicate parallel pathways for viscerosensory signaling. Brain Res 1294:61-79.

Gill CF, Madden JM, Roberts BP, Evans LD, King MS (1999) A subpopulation of neurons in the rat rostral nucleus of the solitary tract that project to the parabrachial nucleus express glutamate-like immunoreactivity. Brain Res 821:251-262. 
Goehler LE, Gaykema RP, Nguyen KT, Lee JE, Tilders FJ, Maier SF, Watkins LR (1999) Interleukin-1beta in immune cells of the abdominal vagus nerve: a link between the immune and nervous systems? Journal Of Neuroscience 19:2799-2806.

Grill HJ (2010) Leptin and the systems neuroscience of meal size control. Front Neuroendocrinol 31:61-78.

Guard DB, Swartz TD, Ritter RC, Burns GA, Covasa M (2009) Blockade of hindbrain NMDA receptors containing NR2 subunits increases sucrose intake. Am J Physiol Regul Integr Comp Physiol 296:R921-928.

Guthmann A, Herbert H (1999) Distribution of metabotropic glutamate receptors in the parabrachial and Kolliker-Fuse nuclei of the rat. Neuroscience 89:873-881.

Hay M, McKenzie H, Lindsley K, Dietz N, Bradley SR, Conn PJ, Hasser EM (1999) Heterogeneity of metabotropic glutamate receptors in autonomic cell groups of the medulla oblongata of the rat. J Comp Neurol 403:486-501.

Herbert H, Bellintani-Guardia B (1995) Morphology and dendritic domains of neurons in the lateral parabrachial nucleus of the rat. J Comp Neurol 354:377-394.

Hetzenauer A, Corti C, Herdy S, Corsi M, Ferraguti F, Singewald N (2008) Individual contribution of metabotropic glutamate receptor (mGlu) 2 and 3 to c-Fos expression pattern evoked by mGlu2/3 antagonism. Psychopharmacology (Berl) 201:1-13.

Hollis JH, Lightman SL, Lowry CA (2005) Lipopolysaccharide has selective actions on subpopulations of catecholaminergic neurons involved in activation of the hypothalamicpituitary-adrenal axis and inhibition of prolactin secretion. J Endocrinol 184:393-406.

Holmes GM, Browning KN, Babic T, Fortna SR, Coleman FH, Travagli RA (2013) Vagal afferent fibres determine the oxytocin-induced modulation of gastric tone. J Physiol 591:3081-3100. 
Hong YH, Kim JY, Lee JH, Chae HG, Jang SS, Jeon JH, Kim CH, Kim J, Kim SJ (2009) Agonist-induced internalization of mGluR1alpha is mediated by caveolin. $\mathbf{J}$ Neurochem 111:61-71.

Hosoi T, Okuma Y, Matsuda T, Nomura Y (2005) Novel pathway for LPS-induced afferent vagus nerve activation: possible role of nodose ganglion. Auton Neurosci 120:104107.

Huang QH, Hruby VJ, Tatro JB (1999) Role of central melanocortins in endotoxin-induced anorexia. American Journal of Physiology 276:R864-871.

Jean A (1991) [The nucleus tractus solitarius: neuroanatomic, neurochemical and functional aspects]. Archives Internationales De Physiologie, De Biochimie Et De Biophysique 99:A3-52.

Johnson RW, Propes MJ, Shavit Y (1996) Corticosterone modulates behavioral and metabolic effects of lipopolysaccharide. American Journal Of Physiology 270:R192-198.

Jung CY, Choi HS, Ju JS, Park HS, Kwon TG, Bae YC, Ahn DK (2006) Central metabotropic glutamate receptors differentially participate in interleukin-1beta-induced mechanical allodynia in the orofacial area of conscious rats. J Pain 7:747-756.

Kessler JP, Baude A (1999) Distribution of AMPA receptor subunits GluR1-4 in the dorsal vagal complex of the rat: a light and electron microscope immunocytochemical study. Synapse 34:55-67.

Konsman JP, Blomqvist A (2005) Forebrain patterns of c-Fos and FosB induction during cancer-associated anorexia-cachexia in rat. Eur J Neurosci 21:2752-2766.

Konsman JP, Dantzer R (2001) How the immune and nervous systems interact during disease-associated anorexia. Nutrition 17:664-668. 
Konsman JP, Kelley K, Dantzer R (1999) Temporal and spatial relationships between lipopolysaccharide-induced expression of Fos, interleukin-1beta and inducible nitric oxide synthase in rat brain. Neuroscience 89:535-548.

Konsman JP, Veeneman J, Combe C, Poole S, Luheshi GN, Dantzer R (2008) Central nervous action of interleukin-1 mediates activation of limbic structures and behavioural depression in response to peripheral administration of bacterial lipopolysaccharide. Eur J Neurosci 28:2499-2510.

Laflamme N, Rivest S (2001) Toll-like receptor 4: the missing link of the cerebral innate immune response triggered by circulating gram-negative bacterial cell wall components. Faseb Journal 15:155-163.

Lee HY, Whiteside MB, Herkenham M (1998) Area postrema removal abolishes stimulatory effects of intravenous interleukin-1beta on hypothalamic-pituitary-adrenal axis activity and c-fos mRNA in the hypothalamic paraventricular nucleus. Brain Research Bulletin 46:495-503.

Levinger IM (1971) The cerebral ventricles of the rat. J Anat 108:447-451.

Li CS, Smith DV (1997) Glutamate receptor antagonists block gustatory afferent input to the nucleus of the solitary tract. J Neurophysiol 77:1514-1525.

Lin LH, Talman WT (2002) Coexistence of NMDA and AMPA receptor subunits with nNOS in the nucleus tractus solitarii of rat. J Chem Neuroanat 24:287-296.

Lindstrom E, Brusberg M, Hughes PA, Martin CM, Brierley SM, Phillis BD, Martinsson R, Abrahamsson C, Larsson H, Martinez V, Blackshaw LA (2008) Involvement of metabotropic glutamate 5 receptor in visceral pain. Pain 137:295-305.

Loewy AD (1990) Central autonomic pathways. In: Central regulation of autonomic functions (Loewy AD, Spyer KM, eds), pp 88-103. New York: Oxford University Press. 
MacDonald L, Hazi A, Paolini AG, Kent S (2014) Calorie restriction dose-dependently abates lipopolysaccharide-induced fever, sickness behavior, and circulating interleukin-6 while increasing corticosterone. Brain Behav Immun 40:18-26.

Marvel FA, Chen CC, Badr N, Gaykema RP, Goehler LE (2004) Reversible inactivation of the dorsal vagal complex blocks lipopolysaccharide-induced social withdrawal and cFos expression in central autonomic nuclei. Brain Behav Immun 18:123-134.

Mascarucci P, Perego C, Terrazzino S, De Simoni MG (1998) Glutamate release in the nucleus tractus solitarius induced by peripheral lipopolysaccharide and interleukin-1 beta. Neuroscience 86:1285-1290.

Matsunaga W, Miyata S, Takamata A, Bun H, Nakashima T, Kiyohara T (2000) LPS-induced Fos expression in oxytocin and vasopressin neurons of the rat hypothalamus. Brain Res 858:9-18.

Morton GJ, Meek TH, Schwartz MW (2014) Neurobiology of food intake in health and disease. Nat Rev Neurosci 15:367-378.

Nowak L, Bregestovski P, Ascher P, Herbet A, Prochiantz A (1984) Magnesium gates glutamate-activated channels in mouse central neurones. Nature 307:462-465.

Page AJ, Young RL, Martin CM, Umaerus M, O'Donnell TA, Cooper NJ, Coldwell JR, Hulander M, Mattsson JP, Lehmann A, Blackshaw LA (2005) Metabotropic glutamate receptors inhibit mechanosensitivity in vagal sensory neurons. Gastroenterology 128:402-410.

Pardridge WM (2011) Drug transport in brain via the cerebrospinal fluid. Fluids Barriers CNS $8: 7$

Paues J, Engblom D, Mackerlova L, Ericsson-Dahlstrand A, Blomqvist A (2001) Feedingrelated immune responsive brain stem neurons: association with CGRP. Neuroreport 12:2399-2403. 
Petralia RS, Wang YX, Singh S, Wu C, Shi L, Wei J, Wenthold RJ (1997) A monoclonal antibody shows discrete cellular and subcellular localizations of mGluR1 alpha metabotropic glutamate receptors. J Chem Neuroanat 13:77-93.

Rennels ML, Gregory TF, Blaumanis OR, Fujimoto K, Grady PA (1985) Evidence for a 'paravascular' fluid circulation in the mammalian central nervous system, provided by the rapid distribution of tracer protein throughout the brain from the subarachnoid space. Brain Res 326:47-63.

Reyes TM, Sawchenko PE (2002) Involvement of the arcuate nucleus of the hypothalamus in interleukin-1-induced anorexia. J Neurosci 22:5091-5099.

Rinaman L (2011) Hindbrain noradrenergic A2 neurons: diverse roles in autonomic, endocrine, cognitive, and behavioral functions. Am J Physiol Regul Integr Comp Physiol 300:R222-235.

Rinaman L, Card JP, Enquist LW (1993) Spatiotemporal responses of astrocytes, ramified microglia, and brain macrophages to central neuronal infection with pseudorabies virus. J Neurosci 13:685-702.

Sagar SM, Price KJ, Kasting NW, Sharp FR (1995) Anatomic patterns of Fos immunostaining in rat brain following systemic endotoxin administration. Brain Research Bulletin $36: 381-392$.

Sawchenko PE, Swanson LW (1982) Immunohistochemical identification of neurons in the paraventricular nucleus of the hypothalamus that project to the medulla or to the spinal cord in the rat. Journal Of Comparative Neurology 205:260-272.

Scarlett JM, Zhu X, Enriori PJ, Bowe DD, Batra AK, Levasseur PR, Grant WF, Meguid MM, Cowley MA, Marks DL (2008) Regulation of AgRP mRNA transcription and peptide secretion by acute and chronic inflammation. Endocrinology 
Slattery JA, Page AJ, Dorian CL, Brierley SM, Blackshaw LA (2006) Potentiation of mouse vagal afferent mechanosensitivity by ionotropic and metabotropic glutamate receptors. J Physiol 577:295-306.

Swanson LW (1998) Brain Maps: Structure of the Rat Brain, ed 2nd. Amsterdam: Elsevier.

Takase LF, Nogueira MI (2008) Patterns of fos activation in rat raphe nuclei during feeding behavior. Brain Res 1200:10-18.

Treece BR, Covasa M, Ritter RC, Burns GA (1998) Delay in meal termination follows blockade of N-methyl-D-aspartate receptors in the dorsal hindbrain. Brain Res 810:3440.

Vales K, Zach P, Bielavska E (2006) Metabotropic glutamate receptor antagonists but not NMDA antagonists affect conditioned taste aversion acquisition in the parabrachial nucleus of rats. Exp Brain Res 169:50-57.

van Dijk G, Strubbe JH (2003) Time-dependent effects of neuropeptide Y infusion in the paraventricular hypothalamus on ingestive and associated behaviors in rats. Physiol Behav 79:575-580.

Van Houten M, Posner BI (1983) Circumventricular organs: receptors and mediators of direct peptide hormone action on brain. Adv Metab Disord 10:269-289.

Walker K, Reeve A, Bowes M, Winter J, Wotherspoon G, Davis A, Schmid P, Gasparini F, Kuhn R, Urban L (2001) mGlu5 receptors and nociceptive function II. mGlu5 receptors functionally expressed on peripheral sensory neurones mediate inflammatory hyperalgesia. Neuropharmacology 40:10-19.

Wang JQ (1998) Regulation of immediate early gene c-fos and zif/268 mRNA expression in rat striatum by metabotropic glutamate receptor. Brain Res Mol Brain Res 57:46-53. 
Weiland TJ, Anthony-Harvey-Beavis D, Voudouris NJ, Kent S (2006) Metabotropic glutamate receptors mediate lipopolysaccharide-induced fever and sickness behavior. Brain Behav Immun 20:233-245.

Whitaker KW, Reyes TM (2008) Central blockade of melanocortin receptors attenuates the metabolic and locomotor responses to peripheral interleukin-1beta administration. Neuropharmacology 54:509-520.

Winnicka MM, Wisniewski K, Kupczyk-Subotkowska L, Subotkowski W, Mastalerz P (1994) Central activity of 2-amino-3-phosphonopropionic acid (AP3) and its N-methyl analog. Pol J Pharmacol 46:395-401.

Wu Q, Clark MS, Palmiter RD (2012) Deciphering a neuronal circuit that mediates appetite. Nature 483:594-597.

Yoshida K, Nakamura K, Matsumura K, Kanosue K, Konig M, Thiel HJ, Boldogkoi Z, Toth I, Roth J, Gerstberger R, Hubschle T (2003) Neurons of the rat preoptic area and the raphe pallidus nucleus innervating the brown adipose tissue express the prostaglandin E receptor subtype EP3. Eur J Neurosci 18:1848-1860.

Young MR, Fleetwood-Walker SM, Dickinson T, Blackburn-Munro G, Sparrow H, Birch PJ, Bountra C (1997) Behavioural and electrophysiological evidence supporting a role for group I metabotropic glutamate receptors in the mediation of nociceptive inputs to the rat spinal cord. Brain Res 777:161-169.

Young RL, Page AJ, O'Donnell TA, Cooper NJ, Blackshaw LA (2007) Peripheral versus central modulation of gastric vagal pathways by metabotropic glutamate receptor 5 . Am J Physiol Gastrointest Liver Physiol 292:G501-511.

Zhang X, Fogel R (2003) Involvement of glutamate in gastrointestinal vago-vagal reflexes initiated by gastrointestinal distention in the rat. Auton Neurosci 103:19-37. 
Zheng H, Patterson C, Berthoud HR (2002) Behavioral analysis of anorexia produced by hindbrain injections of AMPA receptor antagonist NBQX in rats. Am J Physiol Regul Integr Comp Physiol 282:R147-155. 


\section{Figure legends}

Fig. 2

Cumulative food intake and changes in body weight after brainstem ionotropic glutamate receptor antagonism. Rats were injected intraperitoneally (ip) with saline (Sal) or bacterial lipopolysaccharides (LPS; A, C), phosphate-buffered saline (PBS) or interleukin-1beta (IL1b; B, D) and intracerebroventricularly (i4v) with PBS or an AMPA/kainate/quisqualate receptor antagonist (CNQX). Food intake was estimated by the difference in weight of food pellets measured every two hours after ip injection. * in $\mathrm{C}$ indicates the statistically significant exacerbating effect of i4v CNQX administration on LPS-induced weight loss between 0-6 $\mathrm{h}$ after its administration. Group sizes for CNQX-LPS experiments were: PBS Sal: $\mathrm{n}=11$; CNQX Sal: $n=11$; PBS LPS: $n=11$; CNQX LPS: $n=12$ and for the CNQX-IL-1beta experiment: PBS PBS: n=7; CNQX PBS: $n=7$; IL-1beta: $n=7$; CNQX IL-1beta: $n=7$.

Fig. 2

Cicrulating corticosterone and IL-1beta concentrations. Plasma corticosterone was determined by radioimmunoassay six hours after ip injection of rats with Sal or LPS and i4v administration of PBS or CNQX, an AMPA/kainate/quisqualate receptor antagonist. Plasma IL-1beta was determined by enzyme-linked immunosorbent assay six hours after ip injection of rats with Sal or LPS and $\mathrm{i} 4 \mathrm{v}$ administration of PBS or CNQX, an AMPA/kainate/quisqualate receptor antagonist. * indicates the statistically significant reducing effect of i4v CNQX administration on LPS-induced IL-1beta concentrations $6 \mathrm{~h}$ later.

Fig. 3 
Cumulative food intake and changes in body weight after brainstem metabotropic glutamate receptor antagonism. Rats were injected intraperitoneally (ip) with saline (Sal) or bacterial lipopolysaccharides (LPS; A, C), phosphate-buffered saline (PBS) or interleukin-1beta (IL1b; B, D) and intracerebroventricularly (i4v) with PBS or a group I and II metabotropic receptor antagonist (AP3; B, D). Food intake was estimated by the difference in weight of food pellets measured every two hours after ip injection. ${ }^{*}$ in A indicates the statistically significant food intake-stimulating effect of i4v AP3 administration between 0-6 h after its administration irrespective of whether animals received LPS or saline ip . * in B indicates the statistically significant stimulating effect of i4v AP3 administration on food intake in animals injected ip with PBS between 0-6 h after its administration. Group sizes for the AP3-LPS experiments were: PBS Sal: $n=25$; AP3 Sal: $n=24$; PBS LPS: $n=23$; AP3 LPS: $n=23$ and for the AP3-IL-1beta experiments: PBS PBS: n=15; AP3 PBS: n=14; PBS IL-1beta: n=15; AP3 IL-1beta: $\mathrm{n}=15$.

Fig. 4

Brainstem mGluR1 distribution. mGluR1alpha-immunoreactive neuronal cell bodies were found in the trigeminal motor nucleus $(\mathrm{B}, \mathrm{C})$, facial nucleus and hypoglossal nucleus $(\mathrm{E}, \mathrm{F})$, as well as in the ventrolateral medulla caudal to the facial nucleus from the paragigantocellular to the lateral reticular nucleus $(\mathrm{H}, \mathrm{I})$. mGluR1alpa-positive neurons were also observed throughout the pontine reticular nucleus between the trigeminal motor nucleus and the raphé magnus (B). [ ] outline areas in B, E and $\mathrm{H}$ that are shown in higher magnification in C, F and I, respectively. Scale bar under K represent $200 \mu \mathrm{m}$. Letters on plates from rat brain atlas (Swanson 1998) (A, D and G) indicate positions of structures shown on photomicrographs on the right. V: trigeminal motor nucleus; XIIl: hypoglossal nucleus; DMV: dorsal motor nucleus of the vagus nerve; GRN: gigantocellular reticular 
nucleus; LRN: lateral reticular nucleus; NTS: nucleus of the solitary tract; PB: parabrachial nuclei; PRN: pontine reticular nucleus; RM: raphé magnus.

Fig. 5

Metabotropic glutamate receptor-dependent c-Fos expression in the rostral nucleus of the solitary tract and lateral parabrachial nuclei. Mean numbers of c-Fos-positive cells unilaterally per section in the nucleus of the solitary tract (NTS) rostral to the AP (A) and the lateral parabrachial nuclei (PB) (B) six hours after intraperitoneal (ip) injection of saline (Sal) or bacterial lipopolysaccharides (LPS) and intra-fourth brain ventricle (i4v) administration of phosphate-buffered saline (PBS) a group I and II metabotropic receptor antagonist (AP3). * indicates the statistically significant reduction of ip LPS-induced c-Fos expression by i4v AP3 in $\mathrm{A}$ and the overall significant decrease of the number of c-Fos-immunoreactive nuclei by i4v AP3 in B. Black and white photomicrographs illustrate c-Fos expression in the NTS rostral to the AP of animals that received ip Sal and i4v PBS (C), ip Sal and i44v AP3 (D), ip LPS and i4v PBS (E) or ip LPS and i4v AP3 (F). Color photomicrographs illustrate combined immunohistochemistry for c-Fos (G and I) and mGluR1alpha (H and I) the NTS rostral to the AP. Pseudocolors: red, c-Fos; green, mGluR. No double-labeled neurons were observed. Scale bars in $\mathrm{H}$ and under $\mathrm{K}$ represent $100 \mu \mathrm{m}$. Rectangle on plate from rat brain atlas (Swanson 1998) indicates where photomicrographs were taken (J). Group sizes for c-Fos experiments were, depending on the structure analyzed, PBS Sal: n=6-9; AP3 Sal: n=6-9; PBS LPS: n=6-8; AP3 LPS n=6-9.

Fig. 6 
Dorsal vagal complex metabotropic glutamate receptor 1 expression and neuronal network innervating the stomach. The dorsocaudal brainstem neuronal network innervating the greater curvature of the stomach, as revealed by the presence of pseudorabies-Bartha viral (PRV) particles, included neurons in the dorsal motor nucleus of the vagus (DMV) and NTS (B, D, F, and H). Metabotropic glutamate receptor 1 (mGluR1) expression was not altered by PRV injection (compare A, C, E, and $\mathrm{G}$ to Figure $3 \mathrm{H}$ and $\mathrm{K}$ ). E-H represent higher magnifications of A-D. Scale bar in $\mathrm{H}$ represents $200 \mu \mathrm{m}$ for E-H. Epifluorescent microscopic examination of combined immunohistochemistry for mGluR1alpha (green) and PRV (red) showed that mGluR1-immunoreactive cells in the hypoglossal nucleus, be that rostrally adjacent to the fourth ventricle $(4 \mathrm{v} ; \mathrm{I})$ or caudally adjacent to the central canal $(\mathrm{cc} ; \mathrm{K})$, did not overlap with PRV-positive cells in the DMV and the NTS (J, L). In addition, some lightly stained mGluR1positive cells were also observed in the DMX and to a lesser extent in the NTS. However, confocal microscopic analysis of combined immunohistochemistry for mGluR1alpha (green; M) and PRV (red; N) did not reveal any double labeled cells in the DMX at the interface with the NTS (O). Scale bar under O: $25 \mu \mathrm{m}$. 4v: fourth ventricle; XII: hypoglossal nucleus; cc: central canal; DMV: dorsal motor nucleus of the vagus nerve; NTS: the nucleus of the solitary tract.

Fig. 7

Raphé magnus metabotropic glutamate receptor 1 expression and neuronal network innervating the stomach. Metabotropic glutamate receptor 1 (mGluR1; A, C) expression and innervation of the stomach revealed by the presence of pseudorabies-Bartha viral (PRV) particles (B, D). C-D represent higher magnifications of A-B. Scale bar in D represents 100 $\mu \mathrm{m}$ for $\mathrm{C}$ and D. Epifluorescent microscopic examination of combined immunohistochemistry for mGluR1alpha (green) and PRV (red) resulted in light labeling of the former (E) and robust 
staining of the latter $(\mathrm{F})$. Confocal microscopic analysis of combined immunohistochemistry for mGluR1alpha (green; G) and PRV (red; H) did allow for detection of double-labeled neurons, shown at higher magnification in the bottom row (I-K with $\mathrm{K}$ showing overlap of green and red labels). ml: medial lemniscus; > indicates double-labeled neuron. Scale bar under K represents $25 \mu \mathrm{m}$. 


\begin{tabular}{|c|c|c|c|c|}
\hline $\begin{array}{l}\text { Structure } \\
\qquad \text { Treatments }\end{array}$ & $\begin{array}{c}\text { PBS/Sal } \\
\text { Mean } \pm \text { SEM }\end{array}$ & $\begin{array}{c}\text { AP3/Sal } \\
\text { Mean } \pm \text { SEM }\end{array}$ & $\begin{array}{c}\text { PBS/LPS } \\
\text { Mean } \pm \text { SEM } \\
\end{array}$ & $\begin{array}{c}\text { AP3/LPS } \\
\text { Mean } \pm \text { SEM }\end{array}$ \\
\hline $\begin{array}{l}\text { NTS caudal to AP } \\
\text { 1) i4v AP3 or PBS } \\
\text { 2) ip LPS or Sal }\end{array}$ & $4.67 \pm 1.91$ & $1.82 \pm 0.81$ & $7.19 \pm 1.96$ & $5.65 \pm 1.53$ \\
\hline $\begin{array}{l}\text { NTS at AP } \\
\text { 1) i4v AP3 or PBS } \\
\text { 2) ip LPS or Sal }\end{array}$ & $8.38 \pm 3.32$ & $5.68 \pm 2.23$ & $19.50 \pm 3.35$ & $19.68 \pm 5.15$ \\
\hline $\begin{array}{l}\text { AP } \\
\begin{array}{l}\text { 1) i4v AP3 or PBS } \\
\text { 2) ip LPS or Sal }\end{array}\end{array}$ & $1.25 \pm 0.36$ & $2.40 \pm 0.77$ & $11.64 \pm 3.84$ & $11.08 \pm 4.13$ \\
\hline $\begin{array}{l}\text { Raphé magnus } \\
\begin{array}{r}\text { 1) i4v AP3 or PBS } \\
\text { 2) ip LPS or Sal }\end{array}\end{array}$ & $6.77 \pm 2.64$ & $2.35 \pm 0.48$ & $3.23 \pm 0.58$ & $2.86 \pm 0.39$ \\
\hline $\begin{array}{l}\text { PVH } \\
\qquad \begin{array}{l}\text { 1) i4v AP3 or PBS } \\
\text { 2) ip LPS or Sal }\end{array}\end{array}$ & $36.74 \pm 10.38$ & $42.29 \pm 11.91$ & $84.99 \pm 19.04$ & $70.94 \pm 15.98$ \\
\hline
\end{tabular}

Table 1

Absence of effect of i4v AP3 administration on ip LPS-induced c-Fos expression in structures other than the rostral nucleus of the solitary tract and lateral parabrachial nuclei. Values represent mean numbers of c-Fos-positive cells unilaterally per section \pm SEM. AP: area postrema, NTS: nucleus of the solitary tract, PVH: paraventricular nucleus of the hypothalamus, SEM: Standard Error of the Mean. 

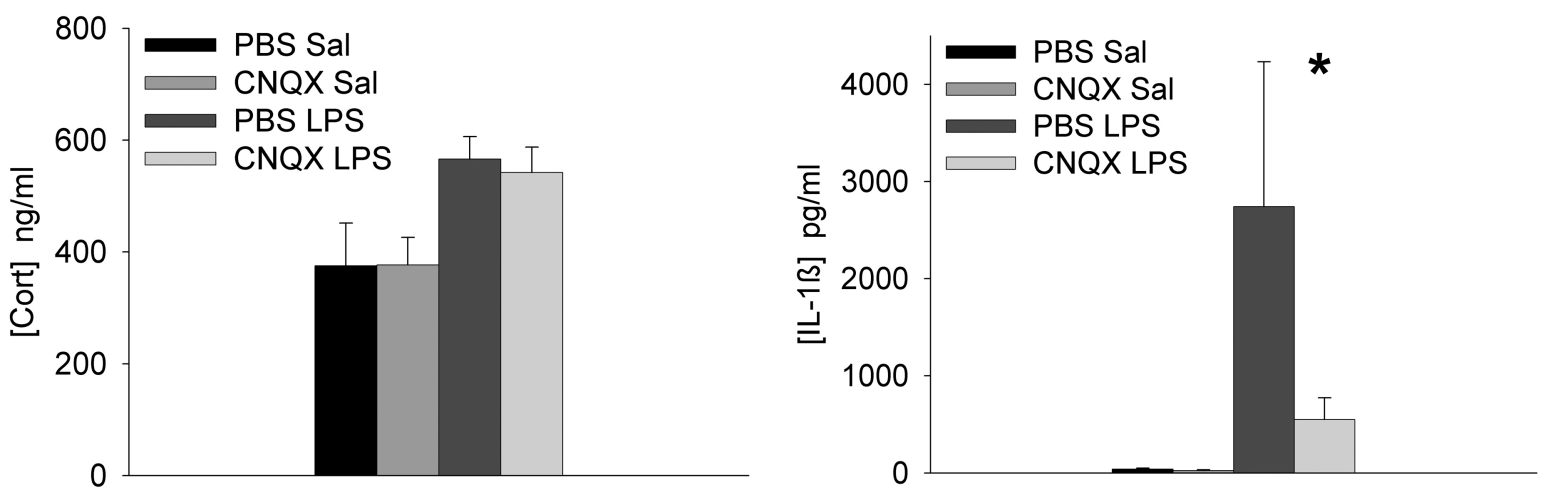
Figure 4

A

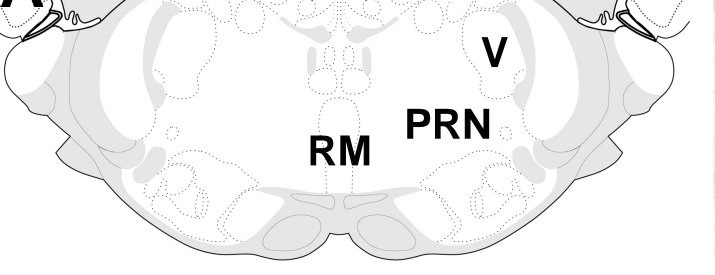

D

XII

SPV $[E]$

GRN

LRN

G

$$
\text { OXIINV SPV }
$$

LRN

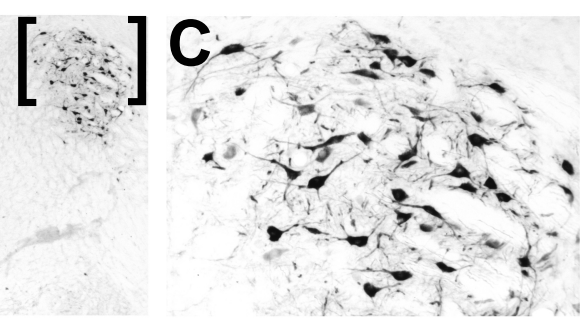

F

H

$[\therefore]$

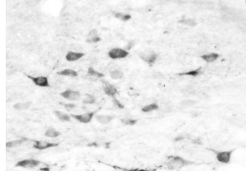

I 

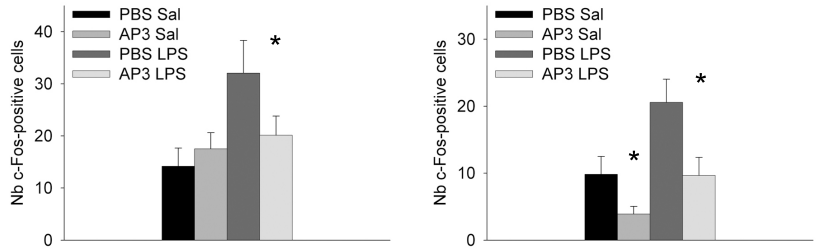

C

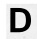

E

F

G
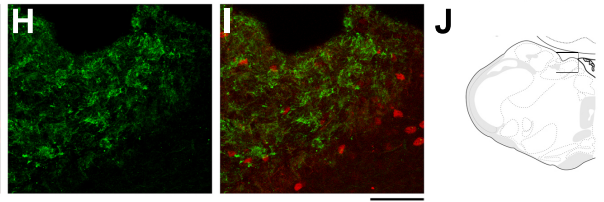


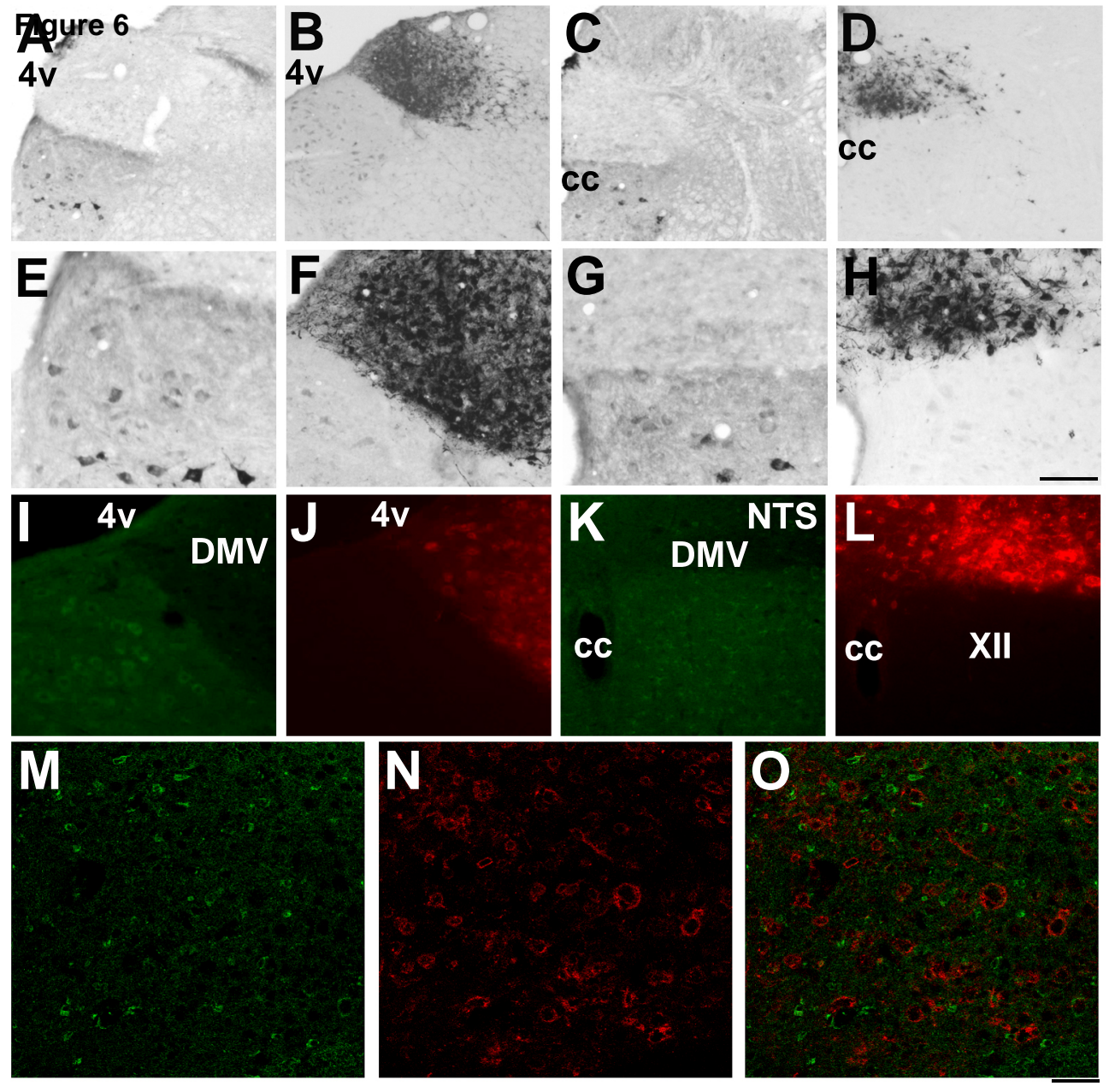


Agure 7

ml

C

s

$\frac{3}{2}+2$

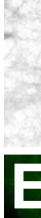

.

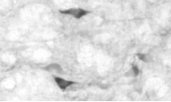

A D
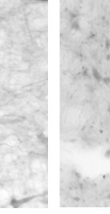

$\mathrm{F}$

$>$

$>$

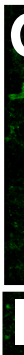

$\mathrm{H}$

4

J

1

9. $\quad \therefore$ 